Prepared in cooperation with the New York State Department of Environmental Conservation

\title{
Groundwater Quality in the Genesee River Basin, New York, 2010
}

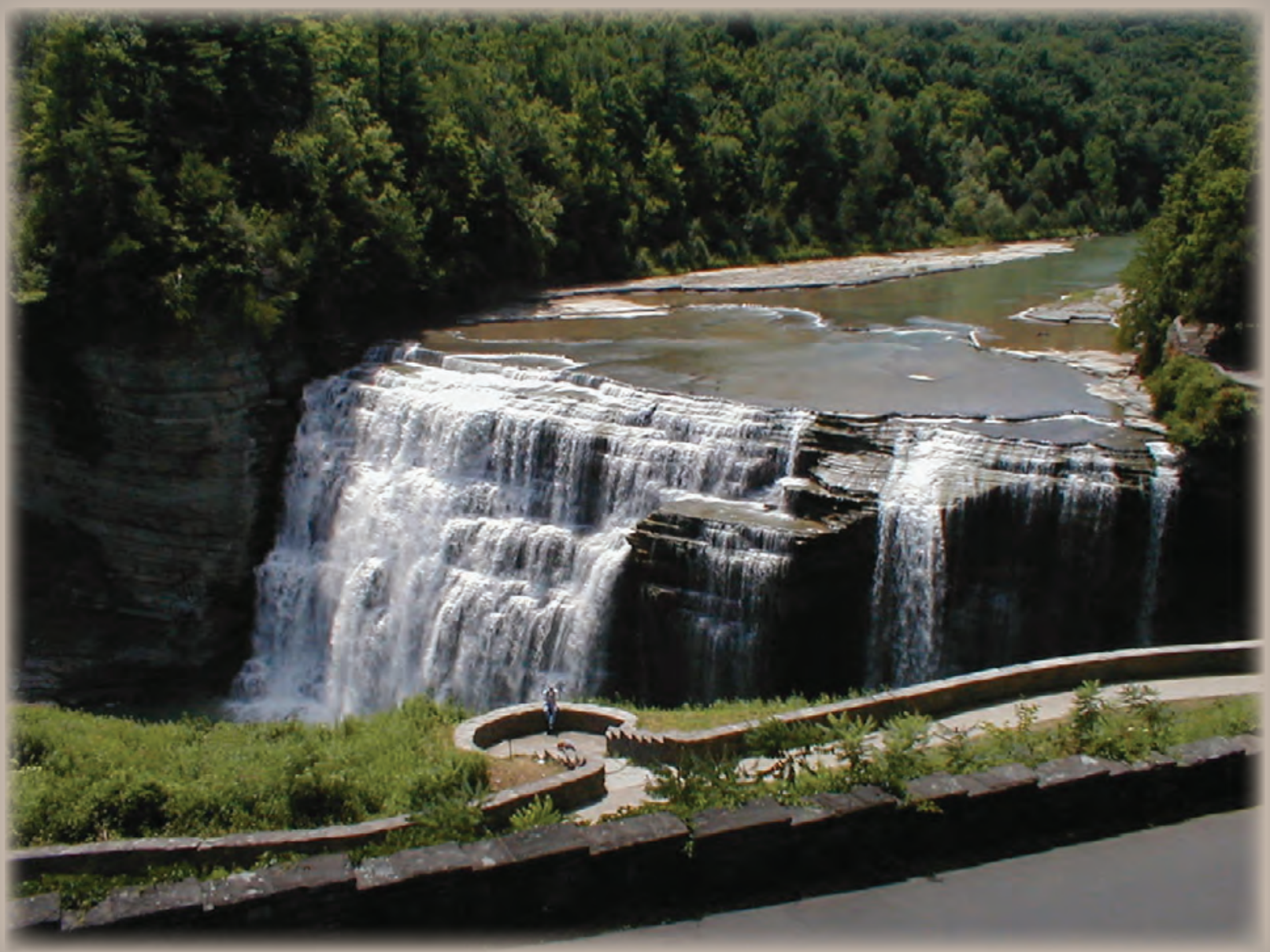

Open-File Report 2012-1135

U.S. Department of the Interior

U.S. Geological Survey 
Cover. Middle Falls of the Genesee River, Letchworth State Park, New York. (Photograph by Nancy Reddy, 2001) 


\section{Groundwater Quality in the Genesee River Basin, New York, 2010}

By James E. Reddy

Prepared in cooperation with the

New York State Department of Environmental Conservation

Open-File Report 2012-1135 


\title{
U.S. Department of the Interior \\ KEN SALAZAR, Secretary \\ U.S. Geological Survey \\ Marcia K. McNutt, Director
}

\author{
U.S. Geological Survey, Reston, Virginia: 2012
}

For more information on the USGS - the Federal source for science about the Earth, its natural and living resources, natural hazards, and the environment, visit http://www.usgs.gov or call 1-888-ASK-USGS.

For an overview of USGS information products, including maps, imagery, and publications,

visit http://www.usgs.gov/pubprod

To order this and other USGS information products, visit http://store.usgs.gov

Any use of trade, firm, or product names is for descriptive purposes only and does not imply endorsement by the U.S. Government.

Although this information product, for the most part, is in the public domain, it also may contain copyrighted materials as noted in the text. Permission to reproduce copyrighted items must be secured from the copyright owner.

Suggested citation:

Reddy, J.E., 2012, Groundwater quality in the Genesee River Basin, New York, 2010: U.S. Geological Survey Open-File Report 2012-1135, 29 p., at http://pubs.usgs.gov/of/2012/1135/. 


\section{Contents}

Conversion Factors, Datum, and Abbreviations ……..................................................................

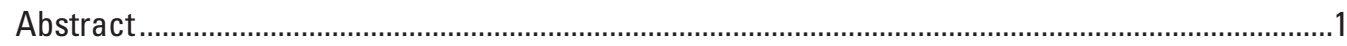

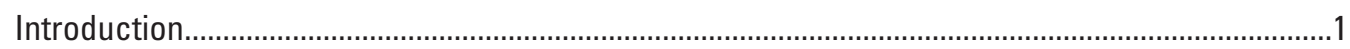

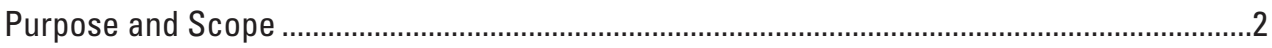

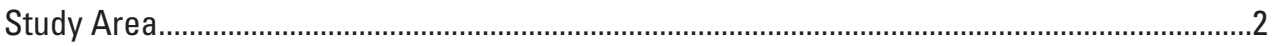

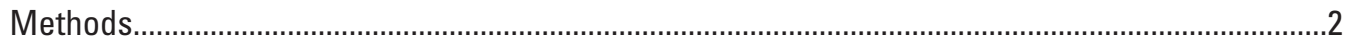

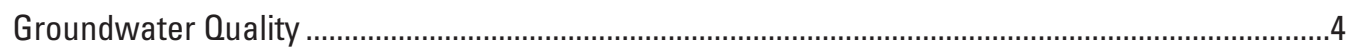

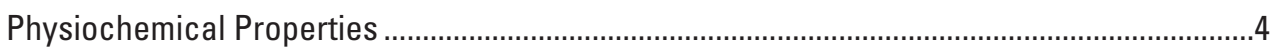

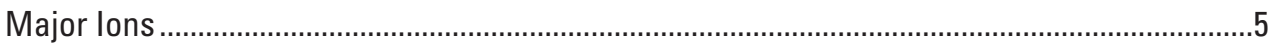

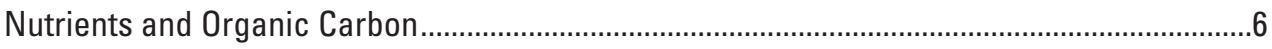

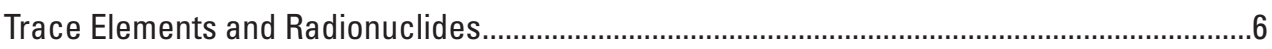

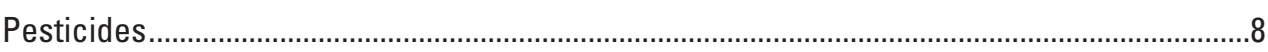

Volatile Organic Compounds......................................................................................... 8

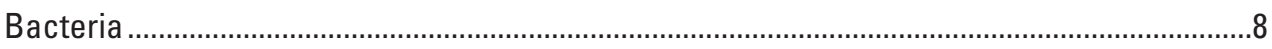

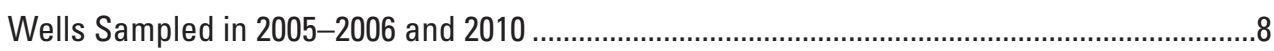

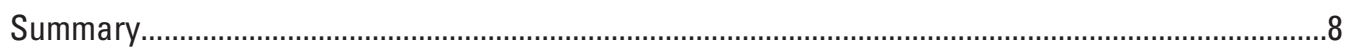

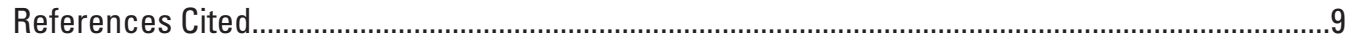

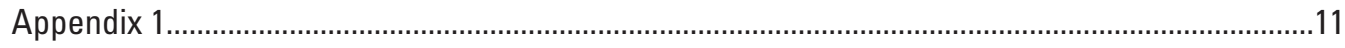

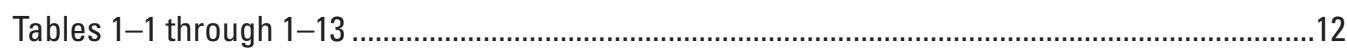

\section{Figures}

1 Map showing pertinent geographic features of study area in the Genesee River Basin, New York, and locations of the 16 wells sampled in 2010.

\section{Tables}

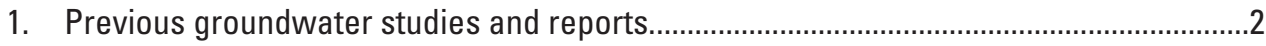

2. Drinking-water standards and summary statistics for concentrations of major ions in groundwater samples from the Genesee River Basin, New York, 2010 ........................5

3. Drinking-water standards and summary statistics for concentrations of nutrients in groundwater samples from the Genesee River Basin, New York, 2010 ............................6

4. Drinking-water standards and summary statistics for concentrations of trace elements and radionuclides in groundwater samples from the Genesee River

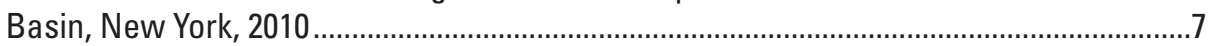

1-1. Information on wells sampled in the Genesee River Basin, New York, 2010....................12

1-2. Compounds for which groundwater samples from the Genesee River Basin, New York, were analyzed but not detected, 2010

1-3. Physiochemical properties of groundwater samples from the Genesee River Basin, New York, 2010

1-4. Concentrations of major ions in groundwater samples from the Genesee River Basin, New York, 2010 
1-5. Concentrations of nutrients and total organic carbon in groundwater samples from the Genesee River Basin, New York, 2010

1-6. Concentrations of trace elements and radionuclides in groundwater samples from the Genesee River Basin, New York, 2010.

1-7. Concentrations of pesticides detected in groundwater samples from the Genesee River Basin, New York, 2010.

1-8. Concentrations of volatile organic compounds in groundwater samples from the Genesee River Basin, New York, 2010.

1-9. Concentrations of bacteria in unfiltered groundwater samples from the Genesee River Basin, New York, 2010.

1-10. Physiochemical properties of and concentrations of major ions, nutrients and total organic carbon, and bacteria in groundwater samples collected in the Genesee River Basin, New York, 2005-2006 and 2010

1-11. Concentrations of trace elements and radionuclides in groundwater samples collected in the Genesee River Basin, New York, 2005-2006 and 2010

1-12. Concentrations of pesticides in groundwater samples collected in the Genesee River Basin, New York, 2005-2006 and 2010.

1-13. Concentrations of volatile organic compounds in groundwater samples collected in the Genesee River Basin, New York, 2005-2006 and 2010. 


\section{Conversion Factors, Datum, and Abbreviations}

\begin{tabular}{|c|c|c|}
\hline Multiply & By & To obtain \\
\hline \multicolumn{3}{|c|}{ Length } \\
\hline inch (in.) & 2.54 & centimeter $(\mathrm{cm})$ \\
\hline foot $(\mathrm{ft})$ & 0.3048 & meter $(\mathrm{m})$ \\
\hline \multicolumn{3}{|c|}{ Area } \\
\hline square mile $\left(\mathrm{mi}^{2}\right)$ & 2.590 & square kilometer $\left(\mathrm{km}^{2}\right)$ \\
\hline \multicolumn{3}{|c|}{ Volume } \\
\hline million gallons (Mgal) & 3,785 & cubic meter $\left(\mathrm{m}^{3}\right)$ \\
\hline \multicolumn{3}{|c|}{ Flow rate } \\
\hline gallon per minute (gal/min) & 0.06309 & liter per second (L/s) \\
\hline gallon per day (gal/d) & 0.003785 & cubic meter per day $\left(\mathrm{m}^{3} / \mathrm{d}\right)$ \\
\hline million gallons per day (Mgal/d) & 0.04381 & cubic meter per second $\left(\mathrm{m}^{3} / \mathrm{s}\right)$ \\
\hline inch per year (in/yr) & 25.4 & millimeter per year (mm/yr) \\
\hline
\end{tabular}

Temperature in degrees Celsius $\left({ }^{\circ} \mathrm{C}\right)$ may be converted to degrees Fahrenheit $\left({ }^{\circ} \mathrm{F}\right)$ as follows:

$$
{ }^{\circ} \mathrm{F}=\left(1.8 \times{ }^{\circ} \mathrm{C}\right)+32
$$

Temperature in degrees Fahrenheit $\left({ }^{\circ} \mathrm{F}\right)$ may be converted to degrees Celsius $\left({ }^{\circ} \mathrm{C}\right)$ as follows:

$$
{ }^{\circ} \mathrm{C}=\left({ }^{\circ} \mathrm{F}-32\right) / 1.8
$$

Vertical coordinate information is referenced to the National Geodetic Vertical Datum of 1929 (NGVD 29).

Horizontal coordinate information is referenced to the North American Datum of 1983 (NAD 83).

Specific conductance is given in microsiemens per centimeter at 25 degrees Celsius $(\mu \mathrm{S} / \mathrm{cm}$ at $\left.25^{\circ} \mathrm{C}\right)$.

Concentrations of chemical constituents in water are given either in milligrams per liter (mg/L) or micrograms per liter ( $\mu \mathrm{g} / \mathrm{L})$.

Laboratory reporting level (LRL) - Generally equal to twice the yearly determined long-term method detection level (LT-MDL). The LRL controls false negative error. The probability of falsely reporting a nondetection for a sample that contained an analyte at a concentration equal to or greater than the LRL is predicted to be less than or equal to 1 percent. The value of the LRL will be reported with a "less than" remark code for samples in which the analyte was not detected. The U.S. Geological Survey's National Water Quality Laboratory collects qualitycontrol data from selected analytical methods on a continuing basis to determine LT-MDLs and to establish LRLs. These values are reevaluated annually based on the most current qualitycontrol data, and, therefore, may change (Childress and others, 1999). 


\section{Abbreviations}

$\begin{array}{ll}\text { AMCL } & \text { Alternative maximum contaminant level } \\ \text { CFCL } & \text { USGS Chlorofluorocarbon Laboratory } \\ \text { CFU/mL } & \text { Colony forming units per milliliter } \\ \text { LRL } & \text { Laboratory reporting level } \\ \text { MCL } & \text { Maximum contaminant level } \\ \text { NWOL } & \text { USGS National Water Quality Laboratory } \\ \text { NYSDEC } & \text { New York State Department of Environmental Conservation } \\ \text { NYSDOH } & \text { New York State Department of Health } \\ \text { OC } & \text { Quality control } \\ \text { SDWS } & \text { Secondary drinking-water standards } \\ \text { THM } & \text { Trihalomethane } \\ \text { USEPA } & \text { U.S. Environmental Protection Agency } \\ \text { USGS } & \text { U.S. Geological Survey } \\ \text { VOC } & \text { Volatile organic compound }\end{array}$

\section{Other abbreviations in this report:}

$\begin{array}{ll}\mu \mathrm{m} & \text { micrometer } \\ \mu \mathrm{g} / \mathrm{L} & \text { micrograms per liter } \\ \mathrm{mg} / \mathrm{L} & \text { milligrams per liter } \\ \mu \mathrm{S} / \mathrm{cm} & \text { microsiemens per centimeter at 25 degrees Celsius } \\ \text { Pt-Co units } & \text { platinum-cobalt units } \\ \mathrm{pCi} / \mathrm{L} & \text { picocuries per liter }\end{array}$




\title{
Groundwater Quality in the Genesee River Basin, New York, 2010
}

\author{
By James E. Reddy
}

\section{Abstract}

Water samples collected from eight production wells and eight private residential wells in the Genesee River Basin from September through December 2010 were analyzed to characterize the groundwater quality in the basin. Eight of the wells were completed in sand and gravel aquifers, and eight were finished in bedrock aquifers. Three of the 16 wells were sampled in the first Genesee River Basin study during 2005-2006. Water samples from the 2010 study were analyzed for 147 physiochemical properties and constituents that included major ions, nutrients, trace elements, radionuclides, pesticides, volatile organic compounds (VOCs), and indicator bacteria. Results of the water-quality analyses are presented in tabular form for individual wells, and summary statistics for specific constituents are presented by aquifer type. The results are compared with Federal and New York State drinking-water standards, which typically are identical. The results indicate that groundwater generally is of acceptable quality, although concentrations of the following constituents exceeded current or proposed Federal or New York State drinking-water standards at each of the 16 wells sampled: color (one sample), sodium (three samples), sulfate (three samples), total dissolved solids (four samples), aluminum (one sample), arsenic (two samples), copper (one sample), iron (nine samples), manganese (eight samples), radon-222 (nine samples), and total coliform bacteria (six samples). Existing drinking-water standards for $\mathrm{pH}$, chloride, fluoride, nitrate, nitrite, antimony, barium, beryllium, cadmium, chromium, lead, mercury, selenium, silver, thallium, zinc, gross alpha radioactivity, uranium, fecal coliform, Escherichia coli, and heterotrophic bacteria were not exceeded in any of the samples collected. None of the pesticides and VOCs analyzed exceeded existing drinkingwater standards.

\section{Introduction}

Section 305(b) of the Federal Clean Water Act Amendments of 1977 requires that States monitor and report biennially on the chemical quality of surface water and groundwater within State boundaries (U.S. Environmental Protection
Agency, 1997). The U.S. Geological Survey (USGS) in 2002, in cooperation with the New York State Department of Environmental Conservation (NYSDEC), developed a program to evaluate groundwater quality throughout the major river basins in New York on a rotating basis. The program parallels the NYSDEC Rotating Intensive Basin Study program, which evaluates surface-water quality in 2 or 3 of the 14 major river basins in the State each year. The groundwater-quality program began in 2002 with a pilot study in the Mohawk River Basin and has continued throughout upstate New York since then (table 1). Sampling completed in 2008 represented the conclusion of a first round of groundwater-quality sampling throughout New York State (excluding Long Island, which is monitored through local county programs). Groundwaterquality sampling was conducted in 2010 in the Delaware, St. Lawrence, and Genesee River Basins; these basins also were sampled in 2005-2006 as part of this program. This report presents the results of the 2010 groundwater study in the Genesee River Basin in west-central New York.

Groundwater characteristics are affected by the geology and the land use of the area. Shallow wells that tap sand and gravel aquifers are susceptible to contamination by several kinds of compounds, including deicing chemicals, nutrients, pesticides, and volatile organic compounds (VOCs) from agricultural, industrial, residential areas, and upgradient highways. The movement of these contaminants to the water table through the soils and surficial sand and gravel can be relatively rapid. Bedrock wells that tap into sandstone and shale aquifers in rural upland areas generally are less susceptible to contamination from industrial and urban sources, which are mainly in the valleys; but bedrock wells in lowland areas underlain by carbonate bedrock (limestone and dolostone) may be more vulnerable to contamination from surface runoff because infiltration rates and groundwater flow can be relatively rapid through bedrock solution features. Agricultural land upgradient of wells may be a potential source of contamination from fecal waste, fertilizers, and pesticides, from livestock; lawns and residential septic systems also are a potential source of these contaminants. In addition to anthropogenic contaminants, the aquifers contain naturally derived constituents that may diminish water quality, such as arsenic, chloride, hydrogen sulfide, iron, manganese, methane, radon gases, sodium, and sulfate. 
Table 1. Previous groundwater studies and reports.

\begin{tabular}{llll}
\hline \multicolumn{1}{c}{ Study Area } & \multicolumn{1}{c}{ Year } & \multicolumn{1}{c}{ Report } & \multicolumn{1}{c}{ Reference } \\
\hline Mohawk River Basin & 2002 & Water-Data Report NY-02-1 & Butch and others, 2003 \\
Chemung River Basin & 2003 & Open-File Report 2004-1329 & Hetcher-Aguila, 2005 \\
Lake Champlain Basin & 2004 & Open-File Report 2006-1088 & Nystrom, 2006 \\
Upper Susquehanna River Basin & $2004-2005$ & Open-File Report 2006-1161 & Hetcher-Aguila and Eckhardt, 2006 \\
Delaware River Basin & $2005-2006$ & Open-File Report 2007-1098 & Nystrom, 2007b \\
Genesee River Basin & $2005-2006$ & Open-File Report 2007-1093 & Eckhardt and others, 2007 \\
St. Lawrence River Basin & $2005-2006$ & Open-File Report 2007-1066 & Nystrom, 2007a \\
Mohawk River Basin & 2006 & Open-File Report 2008-1086 & Nystrom, 2008 \\
Western New York & 2006 & Open-File Report 2008-1140 & Eckhardt and others, 2008 \\
Central New York & 2007 & Open-File Report 2009-1257 & Eckhardt and others, 2009 \\
Upper Hudson River Basin & 2007 & Open-File Report 2009-1240 & Nystrom, 2009 \\
Eastern Lake Ontario Basin & 2008 & Open-File Report 2011-1074 & Risen and Reddy, 2011a \\
Chemung River Basin & 2008 & Open-File Report 2011-1112 & Risen and Reddy, 2011b \\
Lower Hudson River Basin & 2008 & Open-File Report 2010-1197 & Nystrom, 2010 \\
Lake Champlain Basin & 2009 & Open-File Report 2011-1180 & Nystrom, 2011 \\
Upper Susquehanna River Basin & 2009 & Open-File Report 2012-1045 & Reddy and Risen, 2012 \\
Delaware River Basin & 2010 & Open-File Report 2011-1320 & Nystrom, 2012 \\
St. Lawrence River Basin & 2010 & Open-File Report 2011-1320 & Nystrom, 2012 \\
\hline
\end{tabular}

\section{Purpose and Scope}

This report supplements the water-quality study completed in 2005-2006 in the Genesee River Basin (Eckhardt and others, 2007) by resampling 3 of the wells from that study (Wells AG 263, MO 1524, and WO 350), and provides analytical results for 13 new wells (fig. 1). This report briefly describes the study area and the sampling methods, and presents results of the water-quality analyses for the 16 wells sampled in 2010. Summary statistics (number of samples exceeding Federal or State drinking-water standards) and the minimum, median, and maximum concentrations of selected analytes in sand and gravel and bedrock aquifers are provided in tables 2 through 4; information on the sampled wells and detailed analytical results for all analytes are provided in the appendix (tables 1-1 through 1-9).

\section{Study Area}

The Genesee River Basin lies mostly in west-central New York and partly in north-central Pennsylvania (fig. 1). A complete description of the study area is included in the first Genesee River Basin report (Eckhardt and others, 2007). The 2,439-square mile $\left(\mathrm{mi}^{2}\right)$ study area in New York includes all or parts of nine counties. The central and southern parts of the basin lie within the Appalachian Plateau physiographic province, and the northern part of the basin is in the Lake
Ontario Lowlands province (fig. 1). The central and southern parts of the study area are predominantly rural, although there are several large villages [Avon, Dansville, Geneseo, LeRoy, Mount Morris, Warsaw, and Wellsville (fig. 1)] and many small villages and hamlets. Most of the developed area is in the northern part of the basin, including the City of Rochester and its suburbs in Monroe County.

During deglaciation of the region, sand and gravel were deposited by meltwater streams; and clay, silt, and fine sand were deposited in proglacial lakes. The glaciofluvial and glaciolacustrine deposits within the study area are described in detail by Randall (2001) and Coates (1966). The most productive aquifers within the study area are the glaciofluvial deposits of sand and gravel in the valleys. Bedrock aquifers typically are used for water supply in upland areas where sand and gravel aquifers generally are absent. The bedrock aquifers throughout most of the study area are relatively flat-lying, interbedded sedimentary units of shale, siltstone, sandstone, limestone, and dolostone of Silurian and Devonian age (Fisher and others, 1970).

\section{Methods}

A total of 16 wells (appendix table 1-1) were selected for sample collection as described by Eckhardt and others (2007) - 8 were finished in sand and gravel aquifers and 8 


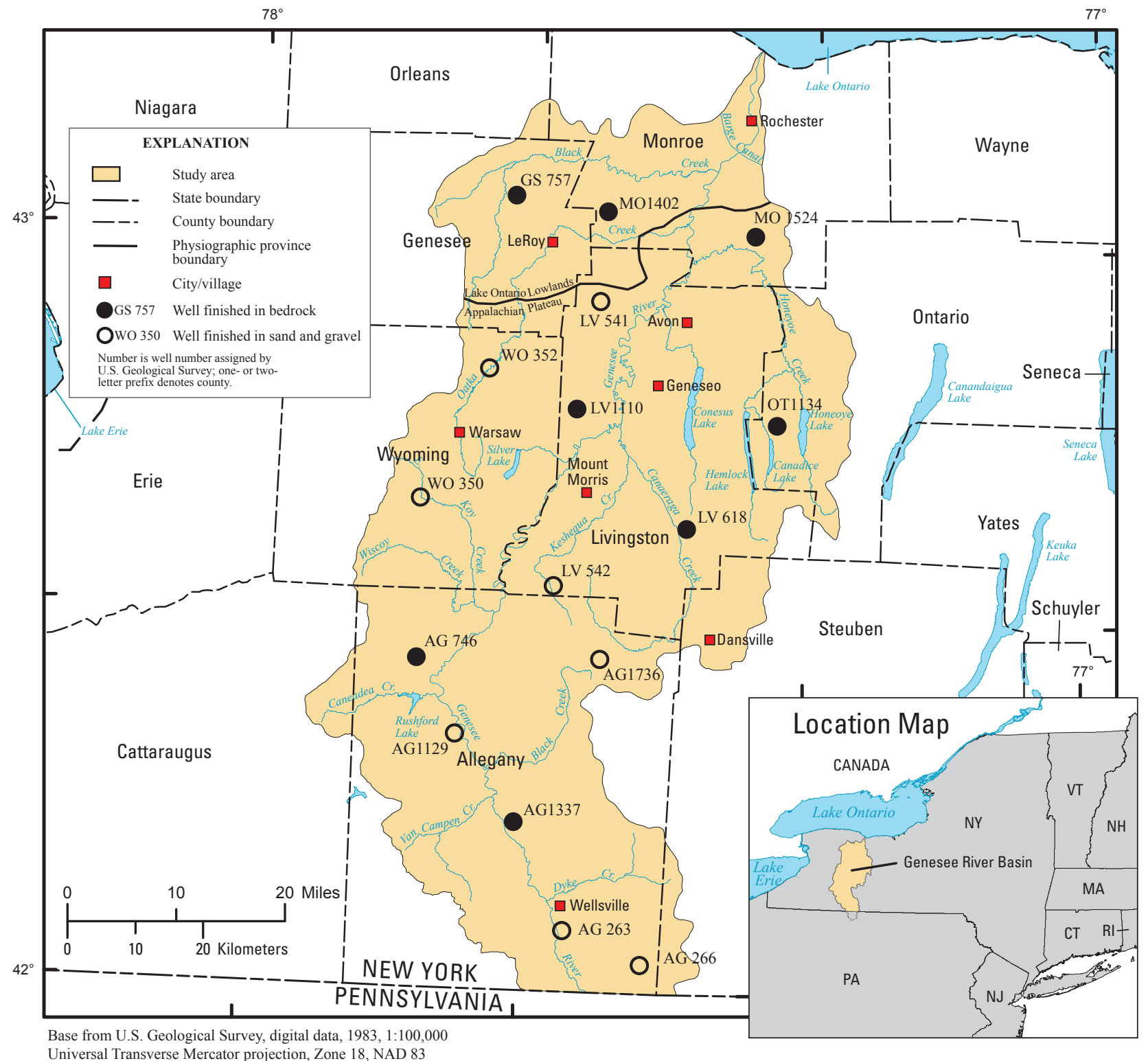

Figure 1. Pertinent geographic features of study area in the Genesee River Basin, New York, and locations of the 16 wells sampled in 2010. (Well data are provided in table 1-1, at end of report.)

were finished in bedrock aquifers. Of the eight wells that tap into sand and gravel aquifers, seven are production wells and one is a private residential well. Of the eight bedrock wells, one is a production well and seven are private residential wells. Samples were collected from September through December 2010. The water samples were analyzed for 147 physiochemical properties and constituents that included major ions, nutrients, trace elements, radionuclides, pesticides, VOCs, and indicator bacteria.

Most of the wells that are finished in sand and gravel were in the valleys and ranged from 25 to $199 \mathrm{ft}$ deep (appendix table 1-1). The wells that are finished in bedrock were generally in the uplands and ranged from 60 to $260 \mathrm{ft}$ deep; all the bedrock wells were finished in sedimentary units of shale, siltstone, and sandstone (appendix table 1-1).

Wells were selected to provide adequate spatial coverage of the study area. The study did not target specific municipalities, industries, or agricultural practices. The private residential wells were selected on the basis of information from the NYSDEC Water Well program, which began in 2000. Production wells were selected using information from the NYSDEC Water Well program and the New York State Department of Health (NYSDOH) Drinking Water Protection program.

In addition to the 16 groundwater samples, one quality control (QC) sample was collected. The 147 physiochemical properties and constituents were divided between a replicate 
sample and a blank sample. A concurrent QC replicate sample was collected for radon-222 and the dissolved gases (argon, carbon dioxide, methane, and nitrogen) and a QC blank sample was collected for the remaining 142 physiochemical properties and constituents. The variability between the replicate sample and the corresponding environmental sample was greatest for radon-222, which was detected at a concentration of 750 picocuries per liter $(\mathrm{pCi} / \mathrm{L})$ in the replicate sample and $780 \mathrm{pCi} / \mathrm{L}$ in the environmental sample - a difference of 3.8 percent. The variability between dissolved gas samples was 1.6 percent or less. Carbon dioxide was the dissolved gas with the greatest variability; the environmental sample had a concentration of $24.6 \mathrm{mg} / \mathrm{L}$ and the concentration of the replicate sample was $25.0 \mathrm{mg} / \mathrm{L}$. No constituents exceeded laboratory reporting levels (LRLs) in the blank sample.

Groundwater-sample collection and processing followed standard USGS procedures as documented in the National Field Manual for the Collection of Water-Quality Data (U.S. Geological Survey, variously dated). All samples except those for radionuclide analyses were chilled to 4 degrees Celsius $\left({ }^{\circ} \mathrm{C}\right)$ or less and were kept chilled until delivery to the analyzing laboratory. The samples were delivered directly, or shipped by overnight delivery, to four laboratories: (1) the USGS National Water Quality Laboratory (NWQL) in Denver, Colorado, for analysis of inorganic major ions, nutrients, total organic carbon, inorganic trace elements, radon-222, pesticides and pesticide degradates, and VOCs; (2) the USGS Chlorofluorocarbon Laboratory (CFCL) in Reston, Virginia, for select dissolved gases; (3) a NYSDOH-certified laboratory in Richmond, California, for gross alpha and gross beta radioactivities; and (4) a NYSDOH-certified laboratory in Depew, New York, for bacterial analysis. Physiochemical properties, such as water temperature, $\mathrm{pH}$, dissolved oxygen concentration, and specific conductance, were measured at the sampling site.

\section{Groundwater Quality}

Samples from 16 wells were analyzed for 147 physiochemical properties and constituents. Many of these (80) were not detected above the LRLs in any sample (appendix table $1-2)$. Results for the remaining 67 physiochemical properties and constituents that were detected are presented in appendix tables 1-3 through 1-9. The categories of physiochemical properties and constituents are presented in the appendix tables as follows: physiochemical properties (table 1-3), inorganic constituents (table 1-4), nutrients and total organic carbon (table 1-5), trace elements and radionuclides (table 1-6), pesticides (table 1-7), VOCs (table 1-8), and bacterial water-quality indicators (table 1-9). Some concentrations were reported as "estimated" when the detected value was less than the established LRL, or when recovery of a compound has been documented to be highly variable (Childress and others, 1999).
Analytical results for selected constituents were compared with Federal and New York State drinking-water standards, which are typically identical. The standards include maximum contaminant levels (MCLs) and secondary drinking-water standards (SDWS) established by the U.S. Environmental Protection Agency (USEPA) (U.S. Environmental Protection Agency, 1999; 2002; and 2009) and the NYSDOH (New York State Department of Health, 2007). The MCLs are enforceable standards that specify the highest level of a contaminant that is allowed in public water drinking supplies; they are not enforceable for private residential wells, but are presented here as a guideline for evaluation of the water-quality results. The SDWS are nonenforceable guidelines based on cosmetic and aesthetic criteria, such as taste, odor, or staining of plumbing fixtures.

The quality of the sampled groundwater generally was acceptable, although in samples from each of the 16 wells the concentration of at least 1 constituent exceeded recommended MCLs or SDWS set by the USEPA and the NYSDOH. Exceedances generally involved minerals and chemical elements that occur from natural interactions of water and rock (aluminum, arsenic, copper, iron, manganese, sodium, and sulfate), but also included radon-222, which is generated from the natural decay of uranium, and total coliform bacteria contamination.

\section{Physiochemical Properties}

The color of the water samples (appendix table 1-3) ranged from less than 1 platinum-cobalt (Pt-Co) unit (the LRL) to $20 \mathrm{Pt}-\mathrm{Co}$ units; the median was less than $5 \mathrm{Pt}-\mathrm{Co}$ units for sand and gravel wells and $2 \mathrm{Pt}-\mathrm{Co}$ units for bedrock wells. The NYSDOH MCL and USEPA SDWS of 15 Pt-Co units were exceeded in one sample from a sand and gravel well. The $\mathrm{pH}$ of the samples ranged from 6.9 to 8.1 ; the median was $\mathrm{pH} 7.6$ for sand and gravel wells and $\mathrm{pH} 7.4$ for bedrock wells. None of the 16 wells had $\mathrm{pH}$ values outside the accepted USEPA SDWS range of pH 6.5 to 8.5 (U.S. Environmental Protection Agency, 2009). Specific conductance of the samples ranged from 293 to 2,510 microsiemens per centimeter $(\mu \mathrm{S} / \mathrm{cm})$ at $25^{\circ} \mathrm{C}$; the median was $593 \mu \mathrm{S} / \mathrm{cm}$ at $25^{\circ} \mathrm{C}$ for sand and gravel wells and $872 \mu \mathrm{S} / \mathrm{cm}$ at $25^{\circ} \mathrm{C}$ for bedrock wells. The temperature of the water ranged from $9.7^{\circ} \mathrm{C}$ to $16.9^{\circ} \mathrm{C}$; the median was $10.5^{\circ} \mathrm{C}$ for sand and gravel wells and $13.4^{\circ} \mathrm{C}$ for bedrock wells.

Dissolved-oxygen concentrations ranged from 0.2 milligrams per liter (mg/L) to $2.7 \mathrm{mg} / \mathrm{L}$; the median was $0.6 \mathrm{mg} / \mathrm{L}$ for sand and gravel wells and $0.4 \mathrm{mg} / \mathrm{L}$ for bedrock wells. Methane concentrations ranged from less than $0.0005 \mathrm{mg} / \mathrm{L}$ (the $\mathrm{LRL}$ ) to $45.4 \mathrm{mg} / \mathrm{L}$; the median was $0.016 \mathrm{mg} / \mathrm{L}$ for sand and gravel wells and $0.005 \mathrm{mg} / \mathrm{L}$ for bedrock wells. The odor of hydrogen sulfide gas, which may occur in the absence of oxygen, was noted by field personnel in water from two sand and gravel wells and three bedrock wells. 


\section{Major Ions}

The cations that were detected in the greatest concentrations were calcium and sodium (table 2 and appendix table 1-4). Calcium concentrations ranged from 22.9 to $544 \mathrm{mg} / \mathrm{L}$; the median was $58.1 \mathrm{mg} / \mathrm{L}$ for sand and gravel wells and 102 $\mathrm{mg} / \mathrm{L}$ for bedrock wells. Magnesium concentrations ranged from 6.03 to $49.5 \mathrm{mg} / \mathrm{L}$; the median was $16.6 \mathrm{mg} / \mathrm{L}$ for sand and gravel wells and $38.7 \mathrm{mg} / \mathrm{L}$ for bedrock wells. Potassium concentrations ranged from 1.06 to $17.5 \mathrm{mg} / \mathrm{L}$; the median was $1.45 \mathrm{mg} / \mathrm{L}$ for sand and gravel wells and $2.78 \mathrm{mg} / \mathrm{L}$ for bedrock wells. Sodium concentrations ranged from 6.14 to $118 \mathrm{mg} / \mathrm{L}$; the median was $32.6 \mathrm{mg} / \mathrm{L}$ for sand and gravel wells and $28.0 \mathrm{mg} / \mathrm{L}$ for bedrock wells. The USEPA nonregulatory drinking-water advisory taste threshold for sodium recommends that sodium concentrations in drinking water not exceed the range of 30 to $60 \mathrm{mg} / \mathrm{L}$ (U.S. Environmental Protection Agency, 2002; 2009). The concentration of sodium in samples from one sand and gravel $(97.4 \mathrm{mg} / \mathrm{L})$ well and two bedrock wells (61.8 and $118 \mathrm{mg} / \mathrm{L})$ exceeded the upper limit of the USEPA threshold.
The anions that were detected in the greatest concentration were bicarbonate and sulfate (table 2 and appendix table 1-4). Bicarbonate concentrations ranged from 76 to 437 $\mathrm{mg} / \mathrm{L}$; the median was $246 \mathrm{mg} / \mathrm{L}$ for sand and gravel wells and $344 \mathrm{mg} / \mathrm{L}$ for bedrock wells. Chloride concentrations ranged from 8.85 to $94.7 \mathrm{mg} / \mathrm{L}$; the median was $54.2 \mathrm{mg} / \mathrm{L}$ for sand and gravel wells and $19.6 \mathrm{mg} / \mathrm{L}$ for bedrock wells. Fluoride concentrations ranged from 0.07 to $0.63 \mathrm{mg} / \mathrm{L}$; the median was $0.14 \mathrm{mg} / \mathrm{L}$ for sand and gravel wells and $0.27 \mathrm{mg} / \mathrm{L}$ for bedrock wells. Silica concentrations ranged from 6.48 to 21.2 $\mathrm{mg} / \mathrm{L}$; the median was $9.15 \mathrm{mg} / \mathrm{L}$ for sand and gravel wells and $13.5 \mathrm{mg} / \mathrm{L}$ for bedrock wells. Sulfate concentrations ranged from $<0.09 \mathrm{mg} / \mathrm{L}$ (the $\mathrm{LRL}$ ) to $1,510 \mathrm{mg} / \mathrm{L}$; the median was $15.6 \mathrm{mg} / \mathrm{L}$ for sand and gravel wells and $75.0 \mathrm{mg} / \mathrm{L}$ for bedrock wells. The NYSDOH MCL and USEPA SDWS of $250 \mathrm{mg} / \mathrm{L}$ were exceeded in samples from three bedrock wells.

Calcium and magnesium contribute to water hardness. Water hardness in the basin ranged from 82 to $1,560 \mathrm{mg} / \mathrm{L}$ (as $\mathrm{CaCO}_{3}$ ); the median was $216 \mathrm{mg} / \mathrm{L}$ for sand and gravel wells and $415 \mathrm{mg} / \mathrm{L}$ for bedrock wells. Three of the samples were soft to moderately hard $\left(120 \mathrm{mg} / \mathrm{L}\right.$ as $\mathrm{CaCO}_{3}$ or less) and 13 wells yielded water that was hard to very hard (greater than

Table 2. Drinking-water standards and summary statistics for concentrations of major ions in groundwater samples from the Genesee River Basin, New York, 2010.

[All concentrations in milligrams per liter in filtered water. --, not applicable; $<$, less than $\mathrm{CaCO}_{3}$, calcium carbonate]

\begin{tabular}{|c|c|c|c|c|c|c|c|c|c|}
\hline & & \multicolumn{8}{|c|}{ Summary statistics and concentrations } \\
\hline & tituent & $\begin{array}{l}\text { Drinking- } \\
\text { water } \\
\text { standard }\end{array}$ & $\begin{array}{l}\text { Number of } \\
\text { samples } \\
\text { exceeding } \\
\text { standard }\end{array}$ & \multicolumn{3}{|c|}{$\begin{array}{l}\text { Sand and gravel } \\
\text { (8 samples) }\end{array}$} & \multicolumn{3}{|c|}{$\begin{array}{c}\text { Bedrock } \\
\text { (8 samples) }\end{array}$} \\
\hline \multirow{3}{*}{$\overbrace{0}^{0}$} & Calcium & -- & -- & 23.7 & 58.1 & 120 & 22.9 & 102 & 544 \\
\hline & Magnesium & -- & -- & 6.80 & 16.6 & 34.4 & 6.03 & 38.7 & 49.5 \\
\hline & Sodium & ${ }^{1} 60$ & 3 & 20.6 & 32.6 & 97.4 & 6.14 & 28.0 & 118 \\
\hline \multirow{4}{*}{ 氞 } & Bicarbonate & -- & -- & 76 & 246 & 437 & 199 & 344 & 429 \\
\hline & Chloride & ${ }^{2,3} 250$ & 0 & 14.1 & 54.2 & 94.7 & 8.85 & 19.6 & 88.9 \\
\hline & Fluoride & $\begin{array}{l}{ }^{4} 4.0 \\
22.0 \\
{ }^{3} 2.2\end{array}$ & 0 & .07 & .14 & .31 & .13 & .27 & .63 \\
\hline & Sulfate & ${ }^{2,3} 250$ & 3 & $<.09$ & 15.6 & 37.4 & $<.18$ & 75.0 & 1,510 \\
\hline \multicolumn{2}{|c|}{ Hardness as $\mathrm{CaCO}_{3}$} & -- & -- & 87 & 216 & 440 & 82 & 415 & 1,560 \\
\hline \multicolumn{2}{|c|}{ Alkalinity as $\mathrm{CaCO}_{3}$} & -- & -- & 62 & 202 & 358 & 163 & 282 & 352 \\
\hline \multicolumn{2}{|c|}{$\begin{array}{l}\text { Dissolved solids, dried } \\
\text { at } 180^{\circ} \mathrm{C}\end{array}$} & 3500 & 4 & 160 & 327 & 539 & 191 & 505 & 2,400 \\
\hline
\end{tabular}

${ }^{1}$ U.S. Environmental Protection Agency Drinking Water Advisory Taste Threshold.

${ }^{2}$ New York State Department of Health Maximum Contaminant Level.

${ }^{3}$ U.S. Environmental Protection Agency Secondary Drinking Water Standard.

${ }^{4}$ U.S. Environmental Protection Agency Maximum Contaminant Level. 
$120 \mathrm{mg} / \mathrm{L}$ as $\mathrm{CaCO}_{3}$ ) (Hem, 1985). Wells finished in bedrock were slightly more alkaline (median $282 \mathrm{mg} / \mathrm{L}$ as $\mathrm{CaCO}_{3}$ ) than those finished in sand and gravel (median $202 \mathrm{mg} / \mathrm{L}$ as $\mathrm{CaCO}_{3}$ ). Concentrations of total dissolved solids ranged from 160 to $2,400 \mathrm{mg} / \mathrm{L}$, with a median of $327 \mathrm{mg} / \mathrm{L}$ for sand and gravel wells and $505 \mathrm{mg} / \mathrm{L}$ for bedrock wells. The USEPA SDWS of $500 \mathrm{mg} / \mathrm{L}$ for dissolved solids was exceeded in one sand and gravel well and three bedrock wells.

\section{Nutrients and Organic Carbon}

Total organic carbon was the predominant nutrient in the groundwater samples (table 3 and appendix table 1-5). Concentrations of ammonia ranged from $<0.010$ (the LRL) to $1.50 \mathrm{mg} / \mathrm{L}$ as nitrogen $(\mathrm{N})$; the median concentration was $0.138 \mathrm{mg} / \mathrm{L}$ as $\mathrm{N}$ in samples from sand and gravel wells and $0.394 \mathrm{mg} / \mathrm{L}$ as N in samples from bedrock wells. Concentrations of nitrate plus nitrite ranged from $<0.02$ (the LRL) to $1.31 \mathrm{mg} / \mathrm{L}$ as $\mathrm{N}$; the median concentration was $<0.02 \mathrm{mg} / \mathrm{L}$ as $\mathrm{N}$ in samples from sand and gravel wells and $<0.04 \mathrm{mg} / \mathrm{L}$ as $\mathrm{N}$ in samples from bedrock wells. The concentration of nitrate plus nitrite did not exceed the USEPA and NYSDOH MCL of $10 \mathrm{mg} / \mathrm{L}$ as $\mathrm{N}$ in any sample. Nitrite was detected in four samples with a maximum concentration of $0.004 \mathrm{mg} / \mathrm{L}$ as N; the concentration of nitrite did not exceed the MCL $(1 \mathrm{mg} / \mathrm{L}$ as $\mathrm{N})$ in any sample. Orthophosphate concentrations ranged from 0.006 to $0.111 \mathrm{mg} / \mathrm{L}$ as phosphorus (P). Organic carbon was detected in 15 of the 16 samples; the maximum concentration was $2.9 \mathrm{mg} / \mathrm{L}$.

\section{Trace Elements and Radionuclides}

The trace elements detected in the greatest concentrations $(>100 \mu \mathrm{g} / \mathrm{L})$ were aluminum, arsenic, barium, boron, copper, iron, manganese, and strontium (table 4 and appendix table 1-6). The largest detected concentration of a trace element, $19,800 \mu \mathrm{g} / \mathrm{L}$, was of strontium in a sample from a bedrock well. The concentration of aluminum in one sample from a bedrock well, $454 \mu \mathrm{g} / \mathrm{L}$, exceeded the upper limit of the USEPA SDWS for aluminum of $200 \mu \mathrm{g} / \mathrm{L}$. The concentration of arsenic in one sample from a sand and gravel well $(148 \mu \mathrm{g} / \mathrm{L})$ and one sample from a bedrock well $(13.3 \mu \mathrm{g} / \mathrm{L})$ exceeded the USEPA and NYSDOH MCL of $10 \mu \mathrm{g} / \mathrm{L}$. The concentration of copper in one sample from a bedrock well $(1,610 \mu \mathrm{g} / \mathrm{L})$ exceeded the USEPA SDWS of $1,000 \mu \mathrm{g} / \mathrm{L}$. The concentration of iron in eight filtered samples and nine unfiltered samples exceeded the USEPA SDWS and the NYSDOH MCL of $300 \mu \mathrm{g} / \mathrm{L}$. The concentration of manganese in seven filtered samples and eight unfiltered samples exceeded the USEPA SDWS of $50 \mu \mathrm{g} / \mathrm{L}$; the NYSDOH MCL of $300 \mu \mathrm{g} / \mathrm{L}$ was not exceeded in any sample. Drinking-water standards for antimony, barium, beryllium, cadmium, chromium, lead, mercury, selenium, silver, thallium, uranium, and zinc were not exceeded; additionally, mercury and thallium were not detected in any sample (appendix table 1-2).

Three measures of radioactivity were employed (table 4 and appendix table 1-6). Gross alpha activity ranged from less than 0.70 to $2.8 \mathrm{pCi} / \mathrm{L}$. The median activity was $<1.2 \mathrm{pCi} / \mathrm{L}$ in samples from sand and gravel wells and $<1.3 \mathrm{pCi} / \mathrm{L}$ in

Table 3. Drinking-water standards and summary statistics for concentrations of nutrients in groundwater samples from the Genesee River Basin, New York, 2010.

[All concentrations in milligrams per liter in filtered water except as noted. N, nitrogen; --, not applicable; <, less than; E, estimated value - constituent was detected in the sample but with low or inconsistent recovery; P, phosphorus]

\begin{tabular}{|c|c|c|c|c|c|c|c|c|}
\hline \multirow{2}{*}{ Constituent } & \multicolumn{8}{|c|}{ Summary statistics and concentrations } \\
\hline & $\begin{array}{l}\text { Drinking- } \\
\text { water } \\
\text { standard }\end{array}$ & $\begin{array}{l}\text { Number of } \\
\text { samples } \\
\text { exceeding } \\
\text { standard }\end{array}$ & \multicolumn{3}{|c|}{$\begin{array}{c}\text { Sand and gravel } \\
\text { (8 samples) }\end{array}$} & \multicolumn{3}{|c|}{$\begin{array}{c}\text { Bedrock } \\
\text { (8 samples) }\end{array}$} \\
\hline Ammonia plus organic $\mathrm{N}$, as $\mathrm{N}$ & -- & -- & $<.05$ & .17 & 1.5 & $<.10$ & .38 & 1.1 \\
\hline Nitrite, as $\mathrm{N}$ & ${ }^{1,2} 1$ & 0 & $<.001$ & $<.001$ & .001 & $<.001$ & $<.002$ & .004 \\
\hline Orthophosphate, as P & -- & -- & .006 & .018 & .111 & .008 & .010 & .013 \\
\hline Total organic carbon, unfiltered & -- & -- & .4 & .7 & 2.4 & $<.3$ & .8 & 2.9 \\
\hline
\end{tabular}

${ }^{1}$ U.S. Environmental Protection Agency Maximum Contaminant Level.

${ }^{2}$ New York State Department of Health Maximum Contaminant Level. 
Table 4. Drinking-water standards and summary statistics for concentrations of trace elements and radionuclides in groundwater samples from the Genesee River Basin, New York, 2010.

[All concentrations in micrograms per liter in unfiltered water except as noted. $<$, less than; E, estimated value — constituent was detected in the sample but with low or inconsistent recovery; --, not applicable; $\mathrm{pCi} / \mathrm{L}$, picocuries per liter; mrem/yr, millirem per year]

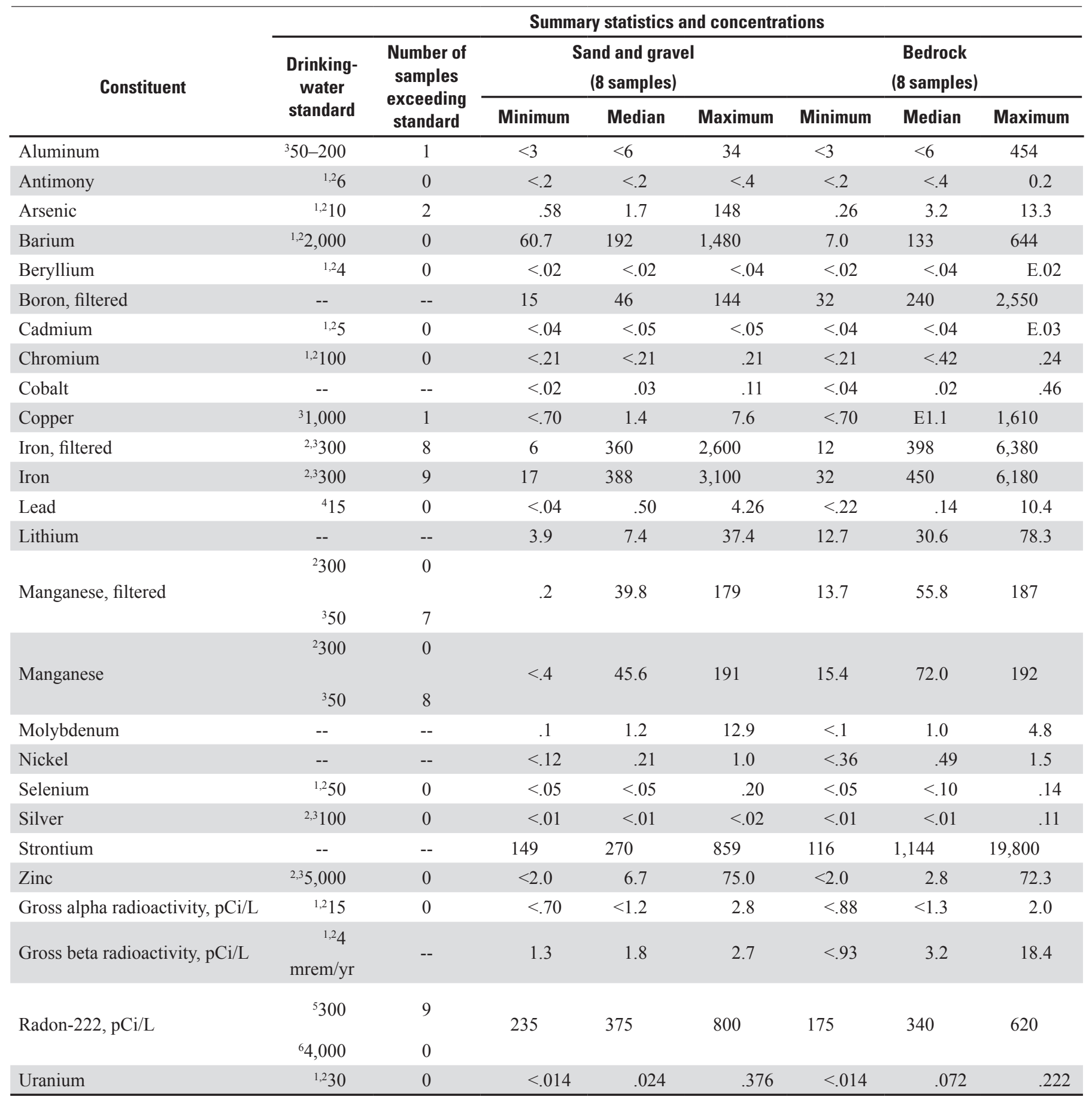

${ }^{1}$ U.S. Environmental Protection Agency Maximum Contaminant Level.

${ }^{2}$ New York State Department of Health Maximum Contaminant Level.

${ }^{3}$ U.S. Environmental Protection Agency Secondary Drinking Water Standard.

${ }^{4}$ U.S. Environmental Protection Agency Treatment Technique.

${ }^{5}$ U.S. Environmental Protection Agency Proposed Maximum Contaminant Level.

${ }^{6}$ U.S. Environmental Protection Agency Proposed Alternative Maximum Contaminant Level. 
samples from bedrock wells. The gross alpha activity did not exceed the USEPA and NYSDOH MCLs for gross alpha of $15 \mathrm{pCi} / \mathrm{L}$ in any sample. Gross beta activity ranged from less than 0.93 to $18.4 \mathrm{pCi} / \mathrm{L}$. The median activity was $1.8 \mathrm{pCi} / \mathrm{L}$ in samples from sand and gravel wells and $3.2 \mathrm{pCi} / \mathrm{L}$ in samples from bedrock wells. The USEPA and NYSDOH MCLs for gross beta are expressed as a dose of 4 millirems per year. Radon-222 was detected in every sample, and activity ranged from 175 to $800 \mathrm{pCi} / \mathrm{L}$. The median activity was $375 \mathrm{pCi} / \mathrm{L}$ in samples from sand and gravel wells and $340 \mathrm{pCi} / \mathrm{L}$ in samples from bedrock wells. Radon currently is not regulated in drinking water; however, the USEPA proposed MCL of $300 \mathrm{pCi} / \mathrm{L}$ for radon-222 in drinking water was exceeded in nine samples, but the USEPA proposed Alternate Maximum Contaminant Level (AMCL) of 4,000 pCi/L was not exceeded. The AMCL is the proposed allowable activity of radon in raw-water samples where the State has implemented mitigation programs to address the health risks of radon in indoor air. The proposed MCL and AMCL for radon are under review and have not been adopted (U.S. Environmental Protection Agency, 1980, 1999, 2009).

\section{Pesticides}

Four pesticides (two herbicides and two insecticides) were detected in samples from three wells (appendix table 1-7). The pesticides were detected in samples from one sand and gravel well and two bedrock wells. All pesticide concentrations were in hundredths or thousandths of micrograms per liter. The constituent detected with the highest concentration $(0.013 \mu \mathrm{g} / \mathrm{L})$ is the insecticide lindane, which was detected in the sample from the sand and gravel well. The herbicide benfluralin was also detected in the sample from the sand and gravel well at a concentration of $0.003 \mu \mathrm{g} / \mathrm{L}$. The insecticide disulfoton was detected in one sample from a bedrock well at an estimated concentration of $0.01 \mu \mathrm{g} / \mathrm{L}$. The presence of the herbicide prometon was verified in one sample from a bedrock well but could not be quantified. None of the pesticides analyzed contained concentrations that exceeded established drinking-water standards.

\section{Volatile Organic Compounds}

Four VOCs were detected in samples from three sand and gravel wells and three bedrock wells (appendix table 1-8). Trichloromethane, bromodichloromethane, and dibromochloromethane were detected in samples from two wells. These three compounds are trihalomethanes (THMs), which typically are formed as byproducts when chlorine or bromine is used to disinfect water. Trichloromethane was detected in a sample from a sand and gravel well at a concentration of 0.1 $\mu \mathrm{g} / \mathrm{L}$, and in a sample from a bedrock well at a concentration of $1.3 \mu \mathrm{g} / \mathrm{L}$. The two other THMs, bromodichloromethane and dibromochloromethane, were also detected in the sample from the bedrock well at concentrations of 0.4 and $0.2 \mu \mathrm{g} / \mathrm{L}$, respectively. Toluene was detected in samples from three sand and gravel wells and two bedrock wells at concentrations ranging from 0.1 to $0.3 \mu \mathrm{g} / \mathrm{L}$. None of the VOCs analyzed exceeded established drinking-water standards.

\section{Bacteria}

All samples were analyzed for Escherichia coli, fecal coliform, heterotrophic bacteria, and total coliform. Total coliform bacteria were detected in six samples (appendix table 1-9) - three from sand and gravel wells and three from bedrock wells. The USEPA and NYSDOH MCL violation for total coliform bacteria occurs when 5 percent of finished water samples collected in 1 month test positive for total coliform (if 40 or more samples are collected per month) or when two samples are positive for total coliform (if fewer than 40 samples are collected per month). Heterotrophic plate counts ranged from 1 to 133 colony-forming units per milliliter $(\mathrm{CFU} / \mathrm{mL})$; the USEPA MCL $(500 \mathrm{CFU} / \mathrm{mL})$ was not exceeded.

\section{Wells Sampled in 2005-2006 and 2010}

Three of the wells sampled in 2010 (Wells AG 263, MO 1524 , and WO 350) were sampled previously in 2005-2006 as part of this program. Of the 147 physiochemical properties and constituents that samples were analyzed for in 2010, 136 were common to 2005-2006 (appendix tables 1-10 through 1-13). The difference between 2005-2006 and 2010 results for a single well were typically smaller than those between the results from different wells. In general, there were no detectable trends in constituent concentrations between 2005-2006 and 2010.

\section{Summary}

In 2002, the U.S. Geological Survey, in cooperation with the New York State Department of Environmental Conservation (NYSDEC), began an assessment of groundwater quality in bedrock and sand and gravel aquifers throughout New York State. As a part of this assessment, the Genesee River Basin was studied in 2005-2006 and again in 2010. The 2010 study is the subject of this report and includes analysis of 16 water samples collected from 8 production wells and 8 private residential wells from September through December 2010. Water samples were analyzed for 147 physiochemical properties and constituents that included major ions, nutrients, trace elements, radionuclides, pesticides, VOCs, and indicator bacteria. Three wells (AG 263, MO1524, and WO 350) were tested in both studies and a comparison was made of the results. The concentrations of most of the constituents changed little between 2005-2006 and 2010. 
The results indicate that groundwater generally is of acceptable quality, although concentrations of the following constituents exceeded current or proposed Federal or New York State drinking-water standards at each of the 16 wells sampled in 2010: color (one sample), sodium (three samples), sulfate (three samples), total dissolved solids (four samples), aluminum (one sample), arsenic (two samples), copper (one sample), iron (nine samples), manganese (eight samples), radon-222 (nine samples), and total coliform bacteria (six samples). Existing drinking-water standards for $\mathrm{pH}$, chloride, fluoride, nitrate, nitrite, antimony, barium, beryllium, cadmium, chromium, lead, mercury, selenium, silver, thallium, zinc, gross alpha radioactivity, uranium, fecal coliform, Escherichia coli, and heterotrophic bacteria were not exceeded in any of the samples collected. None of the pesticides and VOCs analyzed exceeded existing drinking-water standards.

\section{References Cited}

Butch, G.K., Murray, P.M., Hebert, G.J., and Weigel, J.F., 2003, Water Resources Data, New York, Water Year 2002: U.S. Geological Survey Water-Data Report, NY-02-1, p. $502-520$.

Childress, C.J.O., Foreman, W.T., Connor, B.F., and Maloney, T.J., 1999, New reporting procedures based on longterm method detection levels and some considerations for interpretations of water-quality data provided by the U.S. Geological Survey National Water Quality Laboratory: U.S. Geological Survey Open-File Report 99-193, 19 p.

Coates, D.R., 1966, Glaciated Appalachian Plateau-Till shadows on hills: Science, v. 152, p. 1617-1619.

Eckhardt, D.A., Reddy, J.E., and Shaw, S.B., 2009, Groundwater quality in central New York, 2007: U.S. Geological Survey Open-File Report 2009-1257, 40 p., at http://pubs.usgs.gov/of/2009/1257/.

Eckhardt, D.A., Reddy, J.E., and Tamulonis, K.L., 2007, Ground-water quality in the Genesee River Basin, New York, 2005-06: U.S. Geological Survey Open-File Report 2007-1093, 26 p., at http://pubs.usgs.gov/of/2007/1093/.

Eckhardt, D.A., Reddy, J.E., and Tamulonis, K.L., 2008, Ground-water quality in western New York, 2006: U.S. Geological Survey Open-File Report 2008-1140, 36 p., at http://pubs.usgs.gov/of/2008/1140/.

Fisher, D.W., Isachsen, Y.W., and Rickard, L.V., 1970, Geologic map of New York State: New York State Museum Map and Chart Series no. 15, Finger Lakes and Niagara sheets, scale 1:250,000.
Hem, J.D., 1985, Study and interpretation of the chemical characteristics of natural water (3d ed.): U.S. Geological Survey Water-Supply Paper 2254, 264 p.

Hetcher-Aguila, K.K., 2005, Ground-water quality in the Chemung River Basin, New York, 2003: U.S. Geological Survey Open-File Report 04-1329, 19 p., at http://ny.water.usgs.gov/pubs/of/of041329/.

Hetcher-Aguila, K.K., and Eckhardt, D.A., 2006, Groundwater quality in the Upper Susquehanna River Basin, New York, 2004-05: U.S. Geological Survey Open-File Report 06-1161, 20 p., at http://pubs.usgs.gov/of/2006/1161/.

New York State Department of Health, 2007, New York State Health Department public water systems regulations: Albany, N.Y. [variously paged], accessed January 2009, at http://www.health.state.ny.us/environmental/water/drinking/ part5/tables.htm.

Nystrom, E.A., 2006, Ground-water quality in the Lake Champlain Basin, New York, 2004: U.S. Geological Survey Open-File Report 06-1088, 22 p., at http://pubs.usgs.gov/of/2006/1088/.

Nystrom, E.A., 2007a, Ground-water quality in the St. Lawrence River Basin, New York, 2005-2006: U.S. Geological Survey Open-File Report 2007-1066, 33 p., at http://pubs.usgs.gov/of/2007/1066/.

Nystrom, E.A., 2007b, Ground-water quality in the Delaware River Basin, New York, 2001 and 2005-2006: U.S. Geological Survey Open-File Report 2007-1098, 36 p., at http://pubs.usgs.gov/of/2007/1098/.

Nystrom, E.A., 2008, Ground-water quality in the Mohawk River Basin, New York, 2006: U.S. Geological Survey Open-File Report 2008-1086, 33 p., at http://pubs.usgs.gov/of/2008/1086/.

Nystrom, E.A., 2009, Ground-water quality in the Upper Hudson River Basin, New York, 2007: U.S. Geological Survey Open-File Report 2009-1240, 37 p., at http://pubs.usgs.gov/of/2009/1240/.

Nystrom, E.A., 2010, Groundwater quality in the Lower Hudson River Basin, New York, 2008: U.S. Geological Survey Open-File Report 2010-1197, 39 p., at http://pubs.usgs.gov/of/2010/1197/.

Nystrom, E.A., 2011, Groundwater quality in the Lake Champlain Basin, New York, 2009: U.S. Geological Survey Open-File Report 2011-1180, 42 p., at http://pubs.usgs.gov/of/2011/1180/.

Nystrom, E.A., 2012, Groundwater quality in the Delaware and St. Lawrence River Basins, New York, 2010: U.S. Geological Survey Open-File Report 2011-1320, 58 p., at http://pubs.usgs.gov/of/2011/1320/. 
Randall, A.D., 2001, Hydrogeologic framework of stratifieddrift aquifers in the glaciated Northeastern United States: U.S. Geological Survey Professional Paper 1415-B, 179 p.

Risen, A.J., and Reddy, J.E., 2011a, Groundwater quality in the Eastern Lake Ontario Basin, New York, 2008: U.S. Geological Survey Open-File Report 2011-1074, 32 p., at http://pubs.usgs.gov/of/2011/1074/.

Risen, A.J., and Reddy, J.E., 2011b, Groundwater quality in the Chemung River Basin, New York, 2008: U.S. Geological Survey Open-File Report 2011-1112, 25 p., at http:// pubs.usgs.gov/of/2011/1112/.

U.S. Environmental Protection Agency, 1980, Prescribed procedures for measurement of radioactivity in drinking water: EPA 600/4-80-032. (Also available at http://www.epa.gov/ ogwdw000/methods/pdfs/methods/methods_radionuclides. pdf.)

U.S. Environmental Protection Agency, 1997, Guidelines for preparation of the comprehensive state water quality assessments 305(b) reports and electronic updates: Washington, D.C., Office of Water, EPA 841-B-97-002A and EPA 841-B-97-002B, PL 95-217, 271 p.

U.S. Environmental Protection Agency, 1999, Proposed radon in drinking water rule: Washington, D.C., U.S. Environmental Protection Agency, Office of Water, EPA 815-F-99-006, $6 \mathrm{p}$.

U.S. Environmental Protection Agency, 2002, Drinking-water advisory - Consumer acceptability advice and health effects analysis on sodium: Washington, D.C., Office of Water, EPA 822-R-02-032, $34 \mathrm{p}$.

U.S. Environmental Protection Agency, 2009, National primary drinking water standards and national secondary drinking water standards: Washington, D.C., U.S. Environmental Protection Agency, Office of Water, EPA 816-F-09-0004, 6 p. (Also available at http://www.epa.gov/safewater/consumer/pdf/mcl.pdf.)

U.S. Geological Survey, variously dated, National field manual for the collection of water-quality data: U.S. Geological Survey Techniques of Water-Resources Investigations, book 9, chap. A1-A9, available at http://pubs.water.usgs.gov/twri9A. 
Appendix 1.

Tables 1-1 through 1-13 
Table 1-1. Information on wells sampled in the Genesee River Basin, New York, 2010.

[Well locations are shown in figure 1. --, information not available; well types: P, production; D, domestic]

\begin{tabular}{|c|c|c|c|c|c|c|}
\hline $\begin{array}{c}\text { Well } \\
\text { number }\end{array}$ & $\begin{array}{l}\text { U.S. Geological } \\
\text { Survey site } \\
\text { identifier }\end{array}$ & $\begin{array}{c}\text { Date } \\
\text { sampled }\end{array}$ & $\begin{array}{l}\text { Well depth, } \\
\text { feet below } \\
\text { land surface }\end{array}$ & $\begin{array}{l}\text { Casing depth, } \\
\text { feet below } \\
\text { land surface }\end{array}$ & $\begin{array}{l}\text { Well } \\
\text { type }\end{array}$ & Bedrock type \\
\hline \multicolumn{7}{|c|}{ Sand and gravel wells } \\
\hline AG 263 & 421210077921001 & $10 / 6 / 2010$ & 160 & -- & $\mathrm{P}$ & -- \\
\hline AG 266 & 420219077462301 & $11 / 16 / 2010$ & 78 & -- & $\mathrm{P}$ & -- \\
\hline AG1129 & 422018078071901 & $11 / 17 / 2010$ & 199 & 198 & $\mathrm{P}$ & -- \\
\hline AG1736 & 422635077515701 & $12 / 1 / 2010$ & 154 & 154 & $\mathrm{D}$ & -- \\
\hline LV 541 & 425505077531001 & $10 / 5 / 2010$ & 69 & 68 & $\mathrm{P}$ & -- \\
\hline LV 542 & 423219077571701 & $11 / 18 / 2010$ & 52 & -- & $\mathrm{P}$ & -- \\
\hline WO 350 & 426400078130001 & 9/8/2010 & 150 & 150 & $\mathrm{P}$ & -- \\
\hline WO 352 & 424924078045901 & $11 / 2 / 2010$ & 25 & -- & $\mathrm{P}$ & -- \\
\hline \multicolumn{7}{|c|}{ Bedrock wells } \\
\hline AG 746 & 422616078114401 & $9 / 29 / 2010$ & 80 & 31.5 & $\mathrm{D}$ & Shale/siltstone/sandstone \\
\hline AG1337 & 421321078004001 & $9 / 15 / 2010$ & 108 & 19 & $\mathrm{D}$ & Shale/siltstone/sandstone \\
\hline GS 757 & 430330078023901 & $9 / 14 / 2010$ & 75 & 50 & $\mathrm{D}$ & Shale/siltstone/sandstone \\
\hline LV 618 & 423712077423401 & $11 / 10 / 2010$ & 60 & 37.5 & $\mathrm{D}$ & Shale/siltstone/sandstone \\
\hline LV1110 & 424629077552101 & $9 / 28 / 2010$ & 72 & 66 & $\mathrm{D}$ & Shale/siltstone/sandstone \\
\hline MO 1402 & 430221077524001 & $11 / 3 / 2010$ & 73 & 45.5 & $\mathrm{D}$ & Shale/siltstone/sandstone \\
\hline MO 1524 & 430049077362701 & $9 / 23 / 2010$ & 260 & 216 & $\mathrm{D}$ & Shale/siltstone/sandstone \\
\hline OT1134 & 424536077331601 & $10 / 26 / 2010$ & 154 & -- & $\mathrm{P}$ & Shale/siltstone/sandstone \\
\hline
\end{tabular}

${ }^{1}$ Prefix denotes county: AG, Allegany; GS, Genesee; LV, Livingston; MO, Monroe; OT, Ontario; WO, Wyoming; number is local well-identification number assigned by U.S. Geological Survey. 
Table 1-2. Compounds for which groundwater samples from the Genesee River Basin, New York, were analyzed but not detected, 2010.

\begin{tabular}{|c|c|c|}
\hline $\begin{array}{c}\text { U.S. } \\
\text { Geological } \\
\text { Survey } \\
\text { parameter } \\
\text { code }\end{array}$ & Constituent & $\begin{array}{c}\text { Laboratory } \\
\text { reporting level, } \\
\text { micrograms per } \\
\text { liter }^{1}\end{array}$ \\
\hline \multicolumn{3}{|c|}{ Trace elements in unfiltered water } \\
\hline 71900 & Mercury & 0.01 \\
\hline 01059 & Thallium & .12 \\
\hline \multicolumn{3}{|c|}{ Pesticides in filtered water } \\
\hline 82660 & 2,6-Diethylaniline & .006 \\
\hline 04040 & CIAT & $.006-.014$ \\
\hline 49260 & Acetochlor & .01 \\
\hline 46342 & Alachlor & .008 \\
\hline 34253 & alpha-HCH & $.004-.008$ \\
\hline 39632 & Atrazine & $.007-.008$ \\
\hline 82686 & Azinphos-methyl & .120 \\
\hline 04028 & Butylate & $.002-.004$ \\
\hline 82680 & Carbaryl & $.06-.2$ \\
\hline 82674 & Carbofuran & .060 \\
\hline 38933 & Chlorpyrifos & .010 \\
\hline 82687 & cis-Permethrin & .014 \\
\hline 04041 & Cyanazine & $.022-.040$ \\
\hline 82682 & DCPA & $.006-.008$ \\
\hline 62170 & Desulfinyl fipronil & .012 \\
\hline 62169 & Desulfinylfipronil amide & .029 \\
\hline 39572 & Diazinon & .005 \\
\hline 39381 & Dieldrin & .009 \\
\hline 82668 & ЕРТC & .002 \\
\hline 82663 & Ethalfluralin & $.006-.009$ \\
\hline 82672 & Ethoprop & .016 \\
\hline 62167 & Fipronil sulfide & .013 \\
\hline 62168 & Fipronil sulfone & .024 \\
\hline 62166 & Fipronil & $.018-.040$ \\
\hline 04095 & Fonofos & $.004-.010$ \\
\hline 82666 & Linuron & .06 \\
\hline 39532 & Malathion & $.016-.020$ \\
\hline 82667 & Methyl parathion & .008 \\
\hline 39415 & Metolachlor & .014 \\
\hline 82630 & Metribuzin & $.012-.016$ \\
\hline 82671 & Molinate & $.002-.003$ \\
\hline 82684 & Napropamide & $.008-.018$ \\
\hline 34653 & $\mathrm{p}, \mathrm{p}^{\prime}-\mathrm{DDE}$ & $.002-.003$ \\
\hline
\end{tabular}

${ }^{1}$ Constituents with two laboratory reporting levels (LRL) are analytes for which the LRL changed during the course of the sampling.
Table 1-2. Compounds for which groundwater samples from the Genesee River Basin, New York, were analyzed but not detected, 2010.-Continued

\begin{tabular}{|c|c|c|}
\hline $\begin{array}{c}\text { U.S. } \\
\text { Geological } \\
\text { Survey } \\
\text { parameter } \\
\text { code }\end{array}$ & Constituent & $\begin{array}{l}\text { Laboratory } \\
\text { reporting level, } \\
\text { micrograms } \\
\text { per liter }^{1}\end{array}$ \\
\hline \multicolumn{3}{|c|}{ Pesticides in filtered water } \\
\hline 39542 & Parathion & .020 \\
\hline 82669 & Pebulate & .016 \\
\hline 82683 & Pendimethalin & .012 \\
\hline 82664 & Phorate & .020 \\
\hline 04024 & Propachlor & $.006-.012$ \\
\hline 82679 & Propanil & $.010-.014$ \\
\hline 82685 & Propargite & .02 \\
\hline 82676 & Propyzamide & .004 \\
\hline 04035 & Simazine & .006 \\
\hline 82670 & Tebuthiron & $.02-.03$ \\
\hline 82665 & Terbacil & $.024-.040$ \\
\hline 82675 & Terbufos & .02 \\
\hline 82681 & Thiobencarb & .016 \\
\hline 82678 & Triallate & .006 \\
\hline 82661 & Trifluralin & $.012-.018$ \\
\hline \multicolumn{3}{|c|}{ Volatile organic compounds in unfiltered water } \\
\hline 34506 & 1,1,1-Trichloroethane & .1 \\
\hline 77652 & 1,1,1-Trichloro-1,2,2-trifluoroethane & .1 \\
\hline 34496 & 1,1-Dichloroethane & .1 \\
\hline 34501 & 1,1-Dichloroethene & .1 \\
\hline 34536 & 1,2-Dichlorobenzene & .1 \\
\hline 32103 & 1,2-Dichloroethane & .2 \\
\hline 34541 & 1,2-Dichloropropane & .1 \\
\hline 34566 & 1,3-Dichlorobenzene & .1 \\
\hline 34571 & 1,4-Dichlorobenzene & .1 \\
\hline 34030 & Benzene & .1 \\
\hline 34301 & Chlorobenzene & .1 \\
\hline 77093 & cis-1,2-Dichloroethene & .1 \\
\hline 34668 & Dichlorodifluoromethane & .2 \\
\hline 34423 & Dichloromethane & .2 \\
\hline 81576 & Diethyl ether & .2 \\
\hline 81577 & Diisopropyl ether & .2 \\
\hline 34371 & Ethylbenzene & .1 \\
\hline 78032 & Methyl tert-butyl ether & .2 \\
\hline
\end{tabular}

${ }^{1}$ Constituents with two laboratory reporting levels (LRL) are analytes for which the LRL changed during the course of the sampling. 
Table 1-2. Compounds for which groundwater samples from the Genesee River Basin, New York, were analyzed but not detected, 2010.-Continued

\begin{tabular}{lll}
\hline $\begin{array}{c}\text { U.S. } \\
\text { Geological } \\
\begin{array}{c}\text { Survey } \\
\text { parameter } \\
\text { code }\end{array}\end{array}$ & \multicolumn{1}{c}{ Constituent } & \multicolumn{1}{c}{$\begin{array}{c}\text { Laboratory } \\
\text { reporting level, } \\
\text { micrograms per } \\
\text { liter }^{1}\end{array}$} \\
\hline \multicolumn{2}{c}{ Volatile organic compounds in unfiltered water } \\
\hline 50005 & Methyl tert-pentyl ether & .2 \\
85795 & m+p-Xylene & .2 \\
77135 & o-Xylene & .1 \\
77128 & Styrene & .1 \\
50004 & tert-Butyl ethyl ether & .1 \\
34475 & Tetrachloroethene & .1 \\
32102 & Tetrachloromethane & .2 \\
34546 & trans-1,2-Dichloroethene & .1 \\
32104 & Tribromomethane & .2 \\
39180 & Trichloroethene & .1 \\
34488 & Trichlorofluoromethane & .2 \\
39175 & Vinyl Choride & .2 \\
\hline
\end{tabular}

${ }^{1}$ Constituents with two laboratory reporting levels (LRL) are analytes for which the LRL changed during the course of the sampling. 


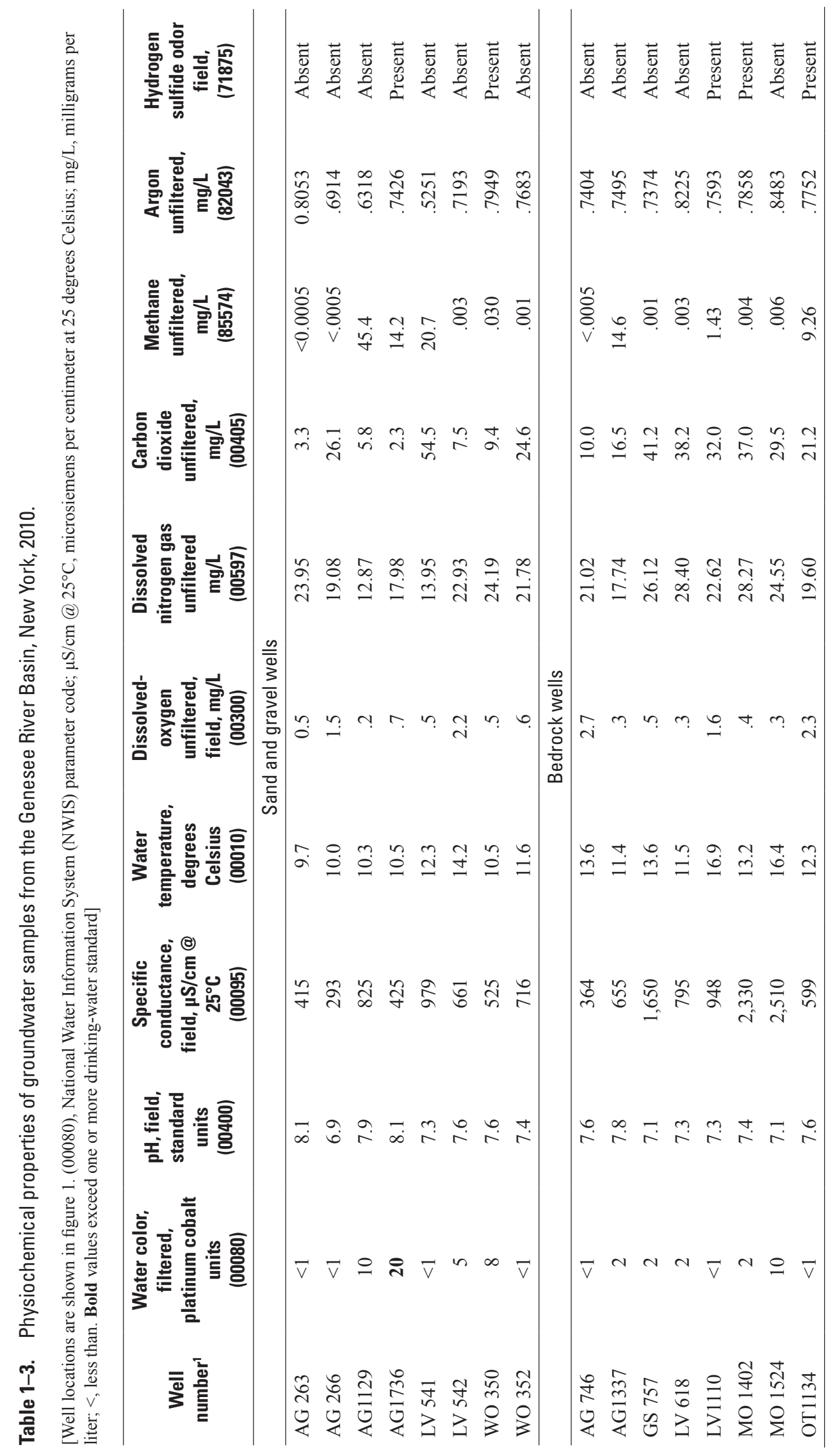


Table 1-4. Concentrations of major ions in groundwater samples from the Genesee River Basin, New York, 2010.

[Well locations are shown in figure 1. mg/L, milligrams per liter; $\mathrm{CaCO}_{3}$, calcium carbonate; (00900), USGS National Water Information System (NWIS) parameter code. Bold values exceed one or more drinking-water standard]

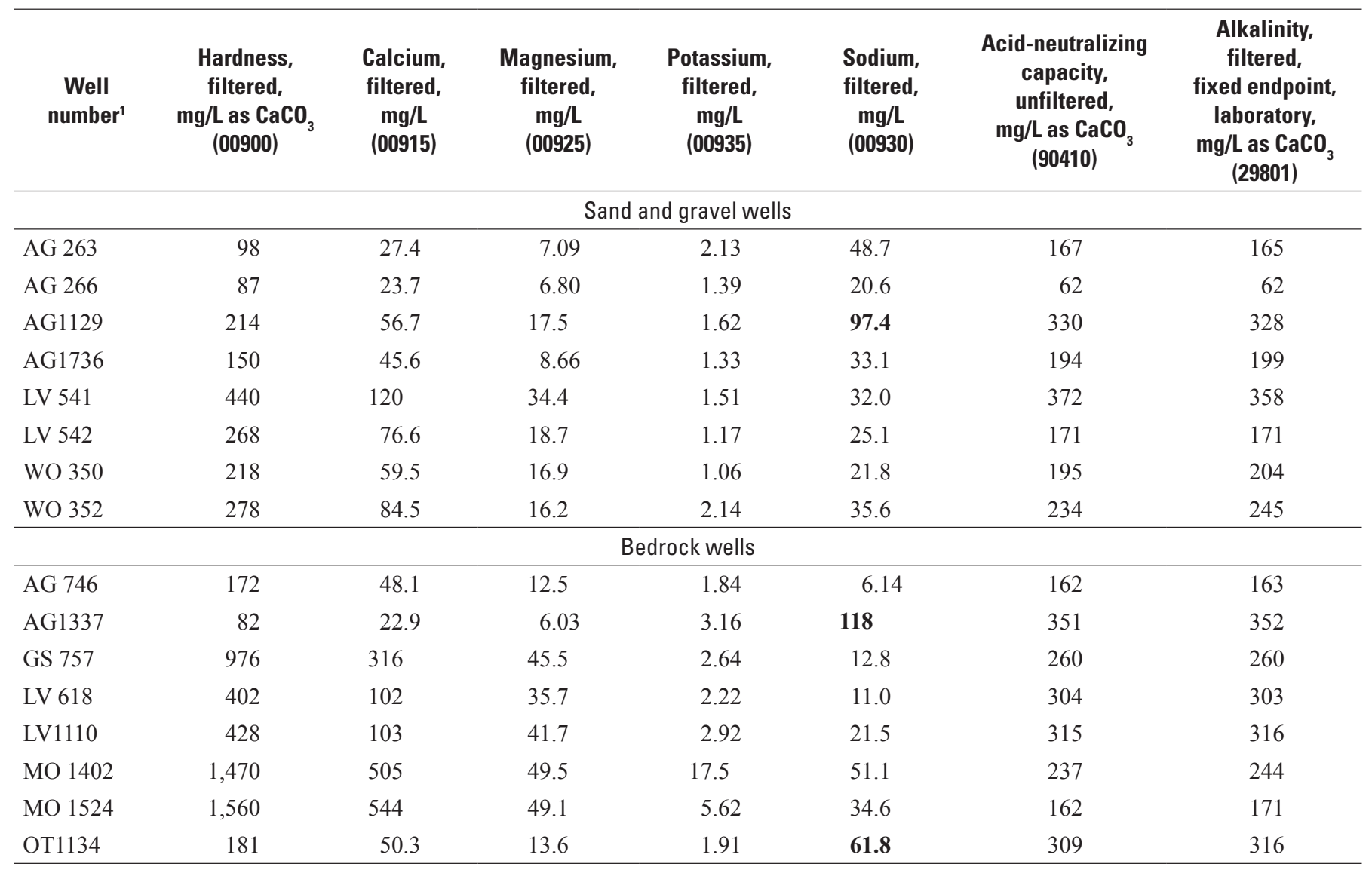

'Prefix denotes county: AG, Allegany; GS, Genesee; LV, Livingston; MO, Monroe; OT, Ontario; WO, Wyoming; number is local well-identification number assigned by U.S. Geological Survey.

${ }^{2}$ Calculated from alkalinity. 
Table 1-4. Concentrations of major ions in groundwater samples from the Genesee River Basin, New York, 2010.—Continued

[Well locations are shown in figure 1. mg/L, milligrams per liter; $\mathrm{CaCO}_{3}$, calcium carbonate; (29805), USGS National Water Information System (NWIS) parameter code; <, less than. Bold values exceed one or more drinking-water standard]

\begin{tabular}{|c|c|c|c|c|c|c|}
\hline $\begin{array}{c}\text { Well } \\
\text { number }^{1}\end{array}$ & $\begin{array}{c}\text { Bicarbonate, } \\
\text { filtered, } \\
\text { mg/L } \\
(29805)\end{array}$ & $\begin{array}{c}\text { Chloride, } \\
\text { filtered, } \\
\text { mg/L } \\
(00940)\end{array}$ & $\begin{array}{c}\text { Fluoride, } \\
\text { filtered, } \\
\text { mg/L } \\
(00950)\end{array}$ & $\begin{array}{c}\text { Silica, } \\
\text { filtered, } \\
\text { mg/L } \\
(00955)\end{array}$ & $\begin{array}{c}\text { Sulfate, } \\
\text { filtered, } \\
\text { mg/L } \\
\text { (00945) }\end{array}$ & $\begin{array}{c}\text { Dissolved solids, } \\
\text { dried at } \\
180^{\circ} \text { Celsius, } \\
\text { filtered, } \\
\mathrm{mg} / \mathrm{L} \\
(70300)\end{array}$ \\
\hline \multicolumn{7}{|c|}{ Sand and gravel wells } \\
\hline AG 263 & 201 & 14.1 & 0.31 & 9.67 & 26.7 & 231 \\
\hline AG 266 & 76 & 40.9 & .08 & 6.48 & 11.7 & 160 \\
\hline AG1129 & 400 & 73.6 & .20 & 8.46 & $<.09$ & 451 \\
\hline AG1736 & 243 & 17.6 & .23 & 8.63 & $<.09$ & 240 \\
\hline LV 541 & 437 & 94.7 & .20 & 21.1 & 3.68 & 539 \\
\hline LV 542 & 209 & 83.0 & .08 & 11.0 & 37.4 & 370 \\
\hline WO 350 & 249 & 34.9 & .09 & 12.7 & 19.4 & 284 \\
\hline WO 352 & 299 & 67.4 & .07 & 7.19 & 28.2 & 386 \\
\hline \multicolumn{7}{|c|}{ Bedrock wells } \\
\hline AG 746 & 199 & 12.9 & .21 & 13.4 & 10.6 & 191 \\
\hline AG1337 & 429 & 9.07 & .23 & 9.77 & $<.18$ & 369 \\
\hline GS 757 & 317 & 28.9 & .31 & 12.1 & 727 & 1,370 \\
\hline LV 618 & 370 & 26.3 & .13 & 16.3 & 98.1 & 481 \\
\hline LV1110 & 386 & 88.9 & .22 & 21.2 & 51.8 & 529 \\
\hline MO 1402 & 298 & 45.3 & .36 & 12.9 & 1,290 & 2,240 \\
\hline MO 1524 & 209 & 10.2 & .63 & 13.8 & 1,510 & 2,400 \\
\hline OT1134 & 386 & 8.85 & .32 & 13.6 & 11.8 & 364 \\
\hline
\end{tabular}

${ }^{1}$ Prefix denotes county: AG, Allegany; GS, Genesee; LV, Livingston; MO, Monroe; OT, Ontario; WO, Wyoming; number is local well-identification number assigned by U.S. Geological Survey.

${ }^{2}$ Calculated from alkalinity. 
Table 1-5. Concentrations of nutrients and total organic carbon in groundwater samples from the Genesee River Basin, New York, 2010.

[Well locations are shown in figure 1. mg/L, milligrams per liter; N, nitrogen; (00623), National Water Information System (NWIS) parameter code; P, phosphorus; <, less than; E, estimated value - constituent was detected in the sample but with low or inconsistent recovery]

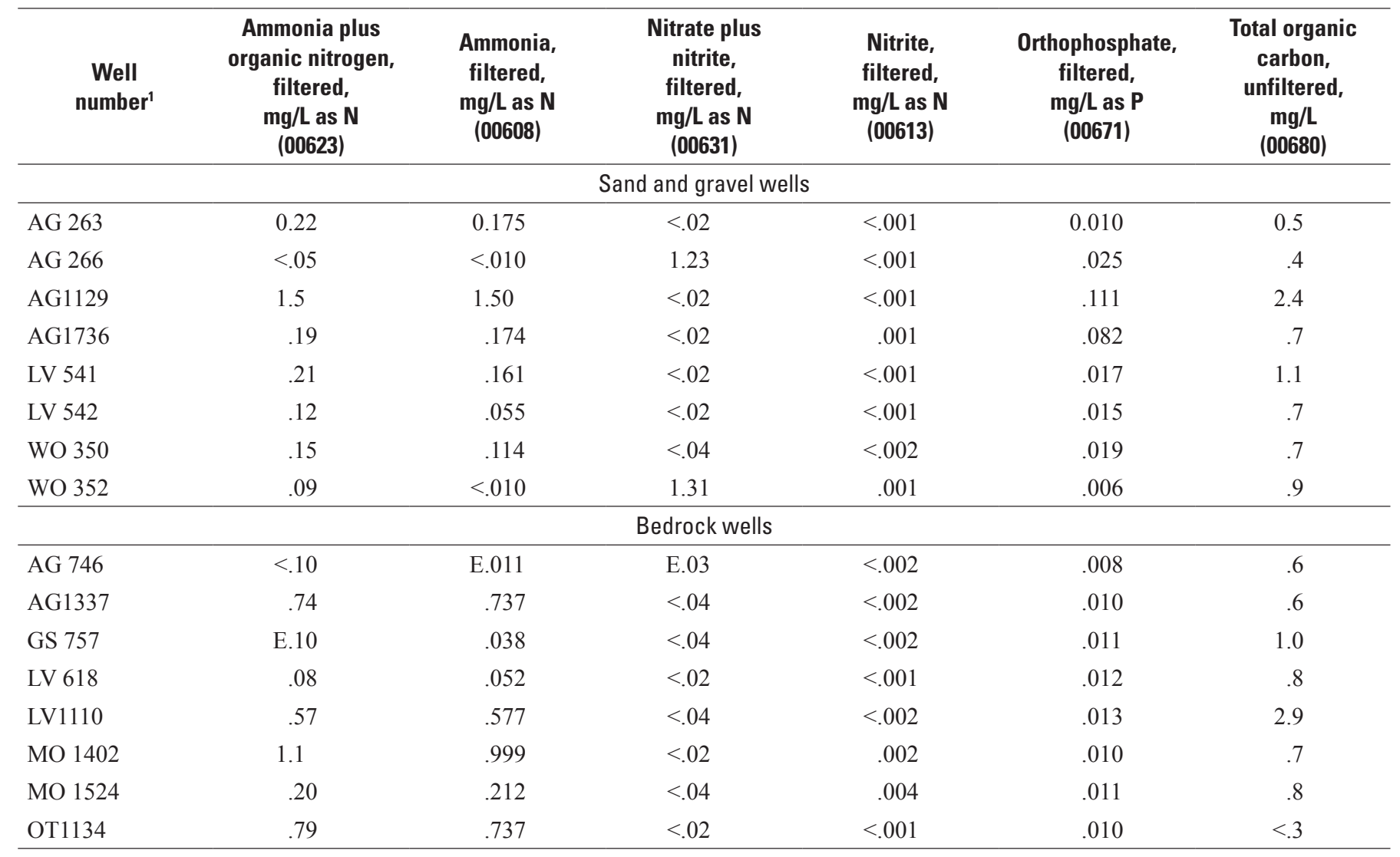

${ }^{1}$ Prefix denotes county: AG, Allegany; GS, Genesee; LV, Livingston; MO, Monroe; OT, Ontario; WO, Wyoming; number is local well-identification number assigned by U.S. Geological Survey. 
Table 1-6. Concentrations of trace elements and radionuclides in groundwater samples from the Genesee River Basin, New York, 2010.

[Well locations are shown in figure 1. $\mu \mathrm{g} / \mathrm{L}$, micrograms per liter; (01105), USGS National Water Information System (NWIS) parameter code; <, less than; E, estimated value — constituent was detected in the sample but with low or inconsistent recovery. Bold values exceed one or more drinking-water standard]

\begin{tabular}{|c|c|c|c|c|c|c|c|c|c|}
\hline $\begin{array}{c}\text { Well } \\
\text { number }^{1}\end{array}$ & $\begin{array}{c}\text { Aluminum, } \\
\text { unfiltered, } \\
\mu \mathrm{g} / \mathrm{L} \\
(\mathbf{0 1 1 0 5 )}\end{array}$ & $\begin{array}{c}\text { Antimony, } \\
\text { unfiltered, } \\
\mu \mathrm{g} / \mathrm{L} \\
(01097)\end{array}$ & $\begin{array}{c}\text { Arsenic, } \\
\text { unfiltered, } \\
\mu \mathrm{g} / \mathrm{L} \\
(01002)\end{array}$ & $\begin{array}{c}\text { Barium, } \\
\text { unfiltered, } \\
\mu \mathrm{g} / \mathrm{L} \\
(01007)\end{array}$ & $\begin{array}{c}\text { Beryllium } \\
\text { unfiltered, } \\
\mu \mathrm{g} / \mathrm{L} \\
(01012)\end{array}$ & $\begin{array}{c}\text { Boron, } \\
\text { filtered, } \\
\mu \mathrm{g} / \mathrm{L} \\
(01020)\end{array}$ & $\begin{array}{c}\text { Cadmium, } \\
\text { unfiltered, } \\
\mu \mathrm{g} / \mathrm{L} \\
(01027)\end{array}$ & $\begin{array}{c}\text { Chromium, } \\
\text { unfiltered, } \\
\mu \mathrm{g} / \mathrm{L} \\
(\mathbf{0 1 0 3 4 )}\end{array}$ & $\begin{array}{c}\text { Cobalt, } \\
\text { unfiltered, } \\
\mu \mathrm{g} / \mathrm{L} \\
(01037)\end{array}$ \\
\hline \multicolumn{10}{|c|}{ Sand and gravel wells } \\
\hline AG 263 & 4 & $<.2$ & 0.89 & 79.3 & $<.02$ & 144 & $<.05$ & $<.21$ & $<.02$ \\
\hline AG 266 & $<3$ & $<.2$ & .58 & 142 & $<.02$ & 19 & $<.05$ & $<.21$ & .02 \\
\hline AG1736 & 4 & $<.2$ & 9.4 & 609 & $<.02$ & 71 & $<.05$ & $<.21$ & .02 \\
\hline LV 541 & 34 & $<.2$ & 1.6 & 1,480 & $<.02$ & 62 & $<.05$ & $<.21$ & .04 \\
\hline LV 542 & $<3$ & $<.2$ & 1.5 & 306 & $<.02$ & 15 & $<.05$ & $<.21$ & .02 \\
\hline WO 350 & $<6$ & $<.4$ & 9.8 & 145 & $<.04$ & 25 & $<.04$ & $<.42$ & .09 \\
\hline AG1337 & $<6$ & $<.4$ & .26 & 539 & $<.04$ & 364 & $<.04$ & $<.42$ & $<.04$ \\
\hline GS 757 & $<6$ & E. 2 & 4.7 & 9.2 & $<.04$ & 117 & $<.04$ & $<.42$ & .10 \\
\hline LV 618 & $<3$ & $<.2$ & 4.5 & 31.2 & $<.02$ & 62 & $<.05$ & $<.21$ & .02 \\
\hline LV1110 & 454 & $<.4$ & 1.8 & 234 & E.02 & 100 & E.03 & $<.42$ & .46 \\
\hline MO 1402 & $<17$ & $<1.1$ & 13.3 & 12.6 & $<.12$ & 2,550 & $<.30$ & $<1.3$ & $<.12$ \\
\hline MO 1524 & $<6$ & $<.4$ & 9.9 & 7.0 & $<.04$ & 552 & $<.04$ & $<.42$ & .08 \\
\hline OT1134 & $<3$ & .2 & 1.1 & 644 & $<.02$ & 433 & $<.05$ & .24 & .02 \\
\hline
\end{tabular}

'Prefix denotes county: AG, Allegany; GS, Genesee; LV, Livingston; MO, Monroe; OT, Ontario; WO, Wyoming; number is local well-identification number assigned by U.S. Geological Survey. 
Table 1-6. Concentrations of trace elements and radionuclides in groundwater samples from the Genesee River Basin, New York, 2010.-Continued

[Well locations are shown in figure 1. pCi/L, picocuries per liter; (01042), USGS National Water Information System (NWIS) parameter code; $\mu \mathrm{g} / \mathrm{L}$, micrograms per liter; <, less than; E, estimated value — constituent was detected in the sample but with low or inconsistent recovery; Bold values exceed one or more drinking-water standard]

\begin{tabular}{|c|c|c|c|c|c|c|c|c|c|}
\hline $\begin{array}{c}\text { Well } \\
\text { number }^{1}\end{array}$ & $\begin{array}{c}\text { Copper, } \\
\text { unfiltered, } \\
\mu \mathrm{g} / \mathrm{L} \\
(01042)\end{array}$ & $\begin{array}{c}\text { Iron, } \\
\text { filtered, } \\
\mu \mathrm{gg} / \mathrm{L} \\
\text { (01046) }\end{array}$ & $\begin{array}{c}\text { Iron, } \\
\text { unfiltered, } \\
\mu \mathrm{g} / \mathrm{L} \\
(01045)\end{array}$ & $\begin{array}{c}\text { Lead, } \\
\text { unfiltered, } \\
\mu \mathrm{g} / \mathrm{L} \\
(01051)\end{array}$ & $\begin{array}{c}\text { Lithium, } \\
\text { unfiltered, } \\
\mu \mathrm{g} / \mathrm{L} \\
(\mathbf{0 1 1 3 2})\end{array}$ & $\begin{array}{c}\text { Manganese, } \\
\text { filtered, } \\
\mu \mathrm{g} / \mathrm{L} \\
(01056)\end{array}$ & $\begin{array}{c}\text { Manganese, } \\
\text { unfiltered, } \\
\mu \mathrm{g} / \mathrm{L} \\
(01055)\end{array}$ & $\begin{array}{l}\text { Molybde- } \\
\text { num, } \\
\text { unfiltered, } \\
\mu \mathrm{gg} / \mathrm{L} \\
(01062)\end{array}$ & $\begin{array}{c}\text { Nickel, } \\
\text { unfiltered, } \\
\mu \mathrm{g} / \mathrm{L} \\
(01067)\end{array}$ \\
\hline \multicolumn{10}{|c|}{ Sand and gravel wells } \\
\hline AG 263 & 3.9 & 10 & 125 & 4.26 & 37.4 & 17.9 & 20.3 & 0.5 & $<.12$ \\
\hline AG1129 & $<.70$ & 1,700 & 1,740 & $<.04$ & 6.0 & 43.4 & 48.3 & 12.9 & .25 \\
\hline AG1736 & $<.70$ & 2,600 & 2,900 & .64 & 12.2 & 179 & 191 & 5.1 & .14 \\
\hline LV 541 & .95 & 2,400 & 3,100 & .51 & 23.5 & 36.3 & 43.0 & .1 & 1.0 \\
\hline LV 542 & 7.6 & 227 & 288 & .73 & 7.8 & 93.4 & 95.4 & 2.0 & .29 \\
\hline WO 350 & E.70 & 493 & 487 & $<.06$ & 7.1 & 76.0 & 81.8 & 3.0 & $<.36$ \\
\hline AG1337 & 3.5 & 94 & 119 & .21 & 69.5 & 13.8 & 15.4 & $<.1$ & E.27 \\
\hline GS 757 & $<1.4$ & 261 & 302 & .18 & 20.8 & 13.7 & 16.1 & 4.8 & .56 \\
\hline LV 618 & .86 & 535 & 597 & .28 & 23.8 & 187 & 192 & 1.4 & .31 \\
\hline LV1110 & 1,610 & 1,850 & 3,710 & 10.4 & 23.0 & 47.6 & 71.8 & .3 & 1.5 \\
\hline MO 1402 & 4.3 & 6,380 & 6,180 & $<.22$ & 55.2 & 69.1 & 72.1 & 1.0 & 1.2 \\
\hline MO 1524 & E1.3 & 1,120 & 2,130 & .10 & 37.5 & 63.9 & 81.5 & 1.5 & .82 \\
\hline OT1134 & $<.70$ & 28 & 32 & .08 & 78.3 & 45.4 & 44.5 & .1 & .42 \\
\hline
\end{tabular}

'Prefix denotes county: AG, Allegany; GS, Genesee; LV, Livingston; MO, Monroe; OT, Ontario; WO, Wyoming; number is local well-identification number assigned by U.S. Geological Survey. 
Table 1-6. Concentrations of trace elements and radionuclides in groundwater samples from the Genesee River Basin, New York, 2010.-Continued

[Well locations are shown in figure 1. $\mu \mathrm{g} / \mathrm{L}$, micrograms per liter; (01147), USGS National Water Information System (NWIS) parameter code; pCi/L, picocuries per liter; <, less than; E, estimated value — constituent was detected in the sample but with low or inconsistent recovery. Bold values exceed one or more drinking-water standard]

\begin{tabular}{|c|c|c|c|c|c|c|c|c|}
\hline $\begin{array}{c}\text { Well } \\
\text { number }^{1}\end{array}$ & $\begin{array}{c}\text { Selenium, } \\
\text { unfiltered, } \\
\mu \mathrm{g} / \mathrm{L} \\
(01147)\end{array}$ & $\begin{array}{c}\text { Silver, } \\
\text { unfiltered, } \\
\mu \mathrm{g} / \mathrm{L} \\
(\mathbf{0 1 0 7 7 )}\end{array}$ & $\begin{array}{c}\text { Strontium, } \\
\text { unfiltered, } \\
\mu \mathrm{g} / \mathrm{L} \\
(\mathbf{0 1 0 8 2})\end{array}$ & $\begin{array}{c}\text { Zinc, } \\
\text { unfiltered, } \\
\mu \mathrm{g} / \mathrm{L} \\
(01092)\end{array}$ & $\begin{array}{c}\text { Gross alpha } \\
\text { radioactivity } \\
\text { pCi/L } \\
(01519)\end{array}$ & $\begin{array}{c}\text { Gross beta } \\
\text { radioactivity } \\
\mathrm{pCi} / \mathrm{L} \\
(85817)\end{array}$ & $\begin{array}{c}\text { Radon-222, } \\
\text { unfiltered, } \\
\text { pCi/L } \\
(\mathbf{8 2 3 0 3 )}\end{array}$ & $\begin{array}{c}\text { Uranium, } \\
\text { unfiltered, } \\
\mu \mathrm{g} / \mathrm{L} \\
(\mathbf{2 8 0 1 1 )}\end{array}$ \\
\hline AG 263 & $<.05$ & $<.01$ & 423 & 19.1 & $<0.99$ & 2.5 & 300 & 0.032 \\
\hline AG 266 & $<.05$ & $<.01$ & 178 & 3.2 & $<.91$ & 2.3 & 800 & .015 \\
\hline AG1736 & $<.05$ & $<.01$ & 290 & $<2.4$ & 2.0 & 2.7 & 370 & $<.014$ \\
\hline LV 541 & $<.05$ & $<.01$ & 859 & 28.8 & $<1.2$ & 1.4 & 235 & $<.014$ \\
\hline LV 542 & $<.05$ & $<.01$ & 151 & 10.2 & $<.70$ & 1.3 & 300 & .285 \\
\hline WO 350 & $<.10$ & $<.02$ & 249 & $<2.0$ & 2.8 & 1.5 & 380 & .275 \\
\hline WO 352 & .20 & $<.01$ & 149 & 75.0 & $<1.2$ & 1.7 & 780 & .376 \\
\hline AG1337 & $<.10$ & $<.02$ & 202 & 3.6 & $<1.1$ & 3.2 & 238 & $<.028$ \\
\hline GS 757 & .14 & .02 & 19,800 & $<2.0$ & $<1.8$ & 3.1 & 175 & .204 \\
\hline LV 618 & $<.05$ & $<.01$ & 249 & 72.3 & $<.88$ & 2.3 & 620 & .099 \\
\hline LV1110 & $<.10$ & .11 & 1,310 & 71.3 & $<1.5$ & 3.5 & 236 & .040 \\
\hline MO 1402 & $<.30$ & $<.09$ & 12,200 & $<14.4$ & $<3.4$ & 18.4 & 380 & .112 \\
\hline MO 1524 & E.07 & E.01 & 10,600 & 3.1 & $<3.3$ & 4.8 & 490 & .222 \\
\hline OT1134 & $<.05$ & $<.01$ & 978 & $<2.4$ & 1.3 & 2.8 & 300 & $<.014$ \\
\hline
\end{tabular}

${ }^{1}$ Prefix denotes county: AG, Allegany; GS, Genesee; LV, Livingston; MO, Monroe; OT, Ontario; WO, Wyoming; number is local well-identification number assigned by U.S. Geological Survey. 
Table 1-7. Concentrations of pesticides detected in groundwater samples from the Genesee River Basin, New York, 2010.

[Well locations are shown in figure 1. $\mu \mathrm{g} / \mathrm{L}$, micrograms per liter; (82673), USGS National Water Information System (NWIS) parameter code; <, less than; M, measured but not quantified; E, estimated value - constituent was detected in the sample but with low or inconsistent recovery]

\begin{tabular}{lcccc}
\hline \multicolumn{1}{c}{$\begin{array}{c}\text { Well } \\
\text { number }\end{array}$} & $\begin{array}{c}\text { Benfluralin, } \\
\text { filtered, } \\
\boldsymbol{\mu g} / \mathbf{L} \\
\mathbf{( 8 2 6 7 3 )}\end{array}$ & $\begin{array}{c}\text { Disulfoton, } \\
\text { filtered, } \\
\mathbf{\mu g} / \mathbf{L} \\
\mathbf{( 8 2 6 7 7 )}\end{array}$ & $\begin{array}{c}\text { Lindane, } \\
\text { filtered, } \\
\mathbf{\mu g} / \mathbf{L} \\
\mathbf{( 3 9 3 4 1 )}\end{array}$ & $\begin{array}{c}\text { Prometon, } \\
\text { filtered, } \\
\boldsymbol{\mu g} / \mathbf{L} \\
\mathbf{( 0 4 0 3 7 )}\end{array}$ \\
\hline AG 263 & $<.014$ & $<.04$ & $<.004$ & $<.01$ \\
AG 266 & $<.014$ & $<.04$ & $<.004$ & $<.01$ \\
AG1129 & .003 & $<.04$ & .013 & $<.01$ \\
AG1736 & $<.014$ & $<.04$ & $<.004$ & $<.01$ \\
LV 541 & $<.014$ & $<.04$ & $<.004$ & $<.01$ \\
LV 542 & $<.014$ & $<.04$ & $<.004$ & $<.01$ \\
WO 350 & $<.014$ & $<.04$ & $<.004$ & $<.01$ \\
WO 352 & $<.014$ & $<.04$ & $<.004$ & $<.01$ \\
\hline & & Bedrock wells & \\
\hline AG 746 & $<.014$ & $<.04$ & $<.004$ & $\mathrm{M}$ \\
AG1337 & $<.014$ & E.01 & $<.004$ & $<.01$ \\
GS 757 & $<.014$ & $<.04$ & $<.004$ & $<.01$ \\
LV 618 & $<.014$ & $<.04$ & $<.004$ & $<.01$ \\
LV1110 & $<.014$ & $<.04$ & $<.004$ & $<.01$ \\
MO 1402 & $<.014$ & $<.04$ & $<.004$ & $<.01$ \\
MO 1524 & $<.014$ & $<.04$ & $<.004$ & $<.01$ \\
OT1134 & $<.014$ & $<.04$ & $<.004$ & $<.01$ \\
\hline
\end{tabular}

${ }^{1}$ Prefix denotes county: AG, Allegany; GS, Genesee; LV, Livingston; MO, Monroe; OT, Ontario; WO, Wyoming; number is local well-identification number assigned by U.S. Geological Survey. 
Table 1-8. Concentrations of volatile organic compounds in groundwater samples from the Genesee River Basin, New York, 2010.

[Well locations are shown in figure 1. $\mu \mathrm{g} / \mathrm{L}$, micrograms per liter; (32106), USGS National Water Information System parameter code; <, less than]

\begin{tabular}{|c|c|c|c|c|}
\hline $\begin{array}{c}\text { Well } \\
\text { number }^{1}\end{array}$ & $\begin{array}{c}\text { Trichloro- } \\
\text { methane, } \\
\text { unfiltered, } \\
\mu \mathrm{g} / \mathrm{L} \\
(32106)\end{array}$ & $\begin{array}{c}\text { Bromo- } \\
\text { dichloro- } \\
\text { methane, } \\
\text { unfiltered, } \\
\mu \mathrm{g} / \mathrm{L} \\
(32101)\end{array}$ & $\begin{array}{c}\text { Dibromo- } \\
\text { chloro- } \\
\text { methane, } \\
\text { unfiltered, } \\
\mu \mathrm{g} / \mathrm{L} \\
(32105)\end{array}$ & $\begin{array}{c}\text { Toluene, } \\
\text { unfiltered, } \\
\mu \mathrm{g} / \mathrm{L} \\
(\mathbf{3 4 0 1 0 )}\end{array}$ \\
\hline \multicolumn{5}{|c|}{ Sand and gravel wells } \\
\hline AG 263 & $<.1$ & $<.1$ & $<.2$ & 0.3 \\
\hline AG 266 & $<.1$ & $<.1$ & $<.2$ & $<.1$ \\
\hline AG1129 & $<.1$ & $<.1$ & $<.2$ & $<.1$ \\
\hline AG1736 & $<.1$ & $<.1$ & $<.2$ & .3 \\
\hline LV 541 & .1 & $<.1$ & $<.2$ & .2 \\
\hline LV 542 & $<.1$ & $<.1$ & $<.2$ & $<.1$ \\
\hline WO 350 & $<.1$ & $<.1$ & $<.2$ & $<.1$ \\
\hline WO 352 & $<.1$ & $<.1$ & $<.2$ & $<.1$ \\
\hline \multicolumn{5}{|c|}{ Bedrock wells } \\
\hline AG 746 & $<.1$ & $<.1$ & $<.2$ & $<.1$ \\
\hline AG1337 & $<.1$ & $<.1$ & $<.2$ & $<.1$ \\
\hline GS 757 & $<.1$ & $<.1$ & $<.2$ & $<.1$ \\
\hline LV 618 & $<.1$ & $<.1$ & $<.2$ & $<.1$ \\
\hline LV1110 & $<.1$ & $<.1$ & $<.2$ & $<.1$ \\
\hline MO 1402 & $<.1$ & $<.1$ & $<.2$ & .1 \\
\hline MO 1524 & 1.3 & .4 & .2 & $<.1$ \\
\hline OT1134 & $<.1$ & $<.1$ & $<.2$ & .3 \\
\hline
\end{tabular}

${ }^{1}$ Prefix denotes county: AG, Allegany; GS, Genesee; LV, Livingston; MO, Monroe; OT, Ontario; WO, Wyoming; number is local well-identification number assigned by U.S. Geological Survey. 
Table 1-9. Concentrations of bacteria in unfiltered groundwater samples from the Genesee River Basin, New York, 2010.

[Well locations are shown in figure 1. mL, milliliter; (61213), National Water Information System (NWIS) parameter code; CFU, colony-forming unit; <, less than; >, greater than. Bold values indicate detections of coliform bacteria]

\begin{tabular}{|c|c|c|c|c|}
\hline $\begin{array}{c}\text { Well } \\
\text { number }{ }^{1}\end{array}$ & $\begin{array}{c}\text { Total coliform } \\
\text { colonies per } 100 \mathrm{~mL} \\
(61213)\end{array}$ & $\begin{array}{c}\text { Fecal coliform } \\
\text { colonies per } 100 \mathrm{~mL} \\
(61215)\end{array}$ & $\begin{array}{c}\text { Escherichia coli, } \\
\text { colonies per } 100 \mathrm{~mL} \\
\text { (31691) }\end{array}$ & $\begin{array}{l}\text { Heterotrophic plate } \\
\text { count, } \\
\text { CFUs per mL } \\
\text { (31692) }\end{array}$ \\
\hline \multicolumn{5}{|c|}{ Sand and gravel wells } \\
\hline AG 263 & 1 & $<1$ & $<1$ & 23 \\
\hline AG 266 & $<1$ & $<1$ & $<1$ & 7 \\
\hline AG1129 & $<1$ & $<1$ & $<1$ & 3 \\
\hline AG1736 & 4 & $<1$ & $<1$ & 6 \\
\hline LV 541 & $<1$ & $<1$ & $<1$ & 133 \\
\hline LV 542 & $<1$ & $<1$ & $<1$ & 9 \\
\hline WO 350 & 250 & $<1$ & $<1$ & 3 \\
\hline WO 352 & $<1$ & $<1$ & $<1$ & 3 \\
\hline \multicolumn{5}{|c|}{ Bedrock wells } \\
\hline AG 746 & 6 & $<1$ & $<1$ & 10 \\
\hline AG1337 & $<1$ & $<1$ & $<1$ & 20 \\
\hline GS 757 & $<1$ & $<1$ & $<1$ & 36 \\
\hline LV 618 & $<1$ & $<1$ & $<1$ & 7 \\
\hline LV1110 & $<1$ & $<1$ & $<1$ & 9 \\
\hline MO 1402 & 4 & $<1$ & $<1$ & 48 \\
\hline MO 1524 & $<1$ & $<1$ & $<1$ & 1 \\
\hline OT1134 & 34 & $<1$ & $<1$ & 1 \\
\hline
\end{tabular}

${ }^{1}$ Prefix denotes county: AG, Allegany; GS, Genesee; LV, Livingston; MO, Monroe; OT, Ontario; WO, Wyoming; number is local well-identification number assigned by U.S. Geological Survey. 
Table 1-10. Physiochemical properties of and concentrations of major ions, nutrients and total organic carbon, and bacteria in groundwater samples collected in the Genesee River Basin, New York, 2005-2006 and 2010.

[Well locations are shown in figure 1. NWIS, National Water Information System; <, less than; mg/L, milligrams per liter; $\mu \mathrm{S} / \mathrm{cm} @ 25^{\circ} \mathrm{C}$, microsiemens per centimeter at 25 degrees Celsius; microsiemens per centimeter at 25 degrees Celsius; $\mathrm{CaCO}_{3}$, calcium carbonate; ${ }^{\circ} \mathrm{C}$, degrees Celcius; $\mathrm{N}$, nitrogen; $\mathrm{U}$, not detected; P, phosphorus; E, estimated value - constituent was detected in the sample but with low or inconsistent recovery; CFU, colony-forming unit; mL, milliliter. Bold values exceed one or more drinking-water standard]

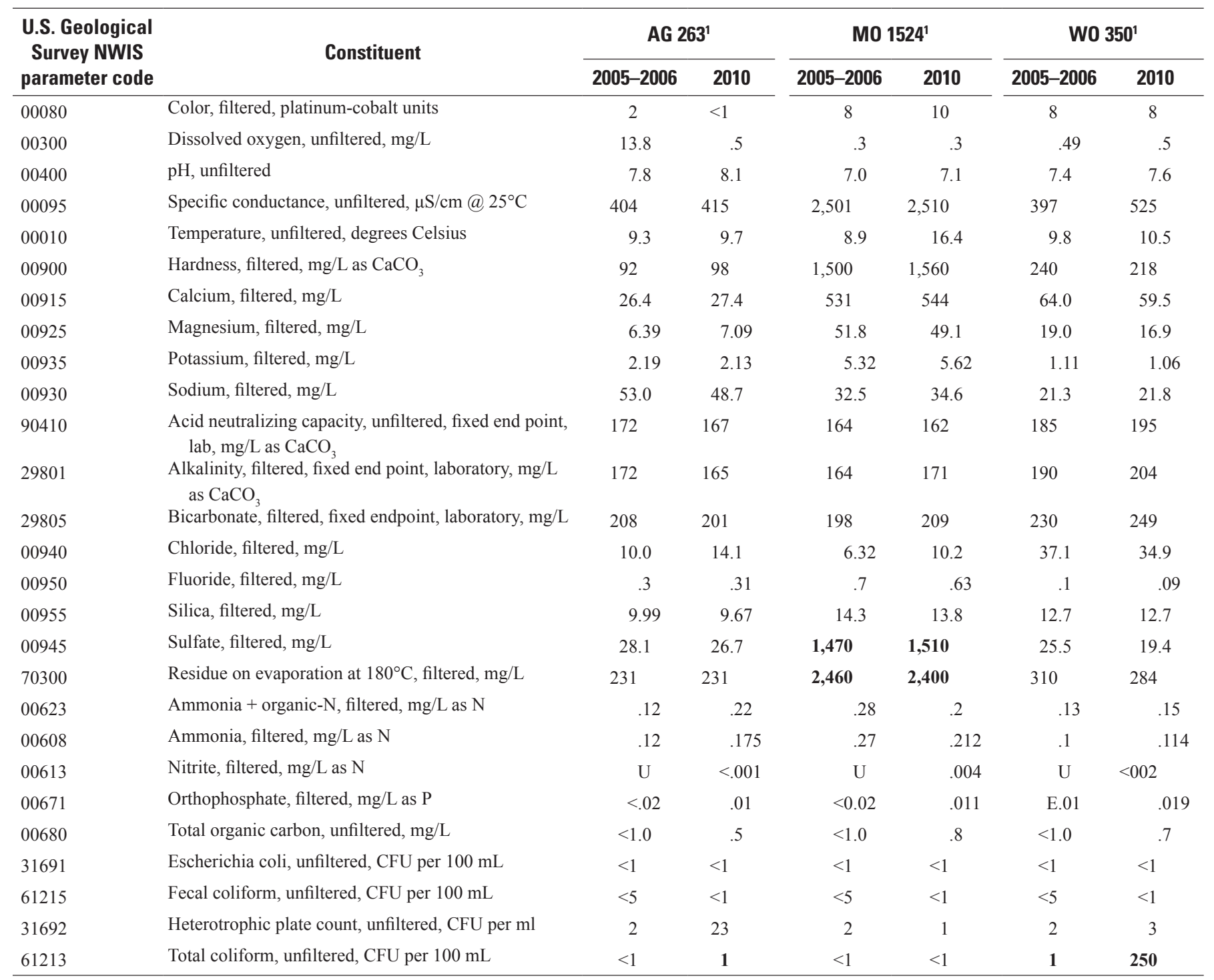

'Prefix denotes county: AG, Allegany; MO, Monroe; WO, Wyoming; number is local well-identification number assigned by U.S. Geological Survey. 
Table 1-11. Concentrations of trace elements and radionuclides in groundwater samples collected in the Genesee River Basin, New York, 2005-2006 and 2010.

[Well locations are shown in figure 1. All concentrations in micrograms per liter except as noted. NWIS, National Water Information System; E, estimated value — constituent was detected in the sample but with low or inconsistent recovery; <, less than; U, not detected; pCi/L, picocuries per liter. Bold values exceed one or more drinking-water standard]

\begin{tabular}{|c|c|c|c|c|c|c|c|}
\hline \multirow{2}{*}{$\begin{array}{c}\text { U.S. Geological } \\
\text { Survey NWIS } \\
\text { parameter } \\
\text { code }\end{array}$} & \multirow{2}{*}{ Constituent } & \multicolumn{2}{|c|}{ AG $263^{1}$} & \multicolumn{2}{|c|}{ MO 1524' } & \multicolumn{2}{|c|}{ WO $350^{1}$} \\
\hline & & 2005-2006 & 2010 & 2005-2006 & 2010 & 2005-2006 & 2010 \\
\hline 01105 & Aluminum, unfiltered & 3 & 4 & E1 & $<6$ & E2 & $<6$ \\
\hline 01097 & Antimony, unfiltered & $<.2$ & $<.2$ & E.1 & $<.4$ & $<.2$ & $<.4$ \\
\hline 01002 & Arsenic, unfiltered & .31 & .89 & .88 & 9.9 & 8.8 & 9.8 \\
\hline 01007 & Barium, unfiltered & 70 & 79.3 & 7 & 7 & 164 & 145 \\
\hline 01020 & Boron, filtered & 145 & 144 & 529 & 552 & 24 & 25 \\
\hline 01027 & Cadmium, unfiltered & $<.04$ & $<.05$ & $<.04$ & $<.04$ & $<.04$ & $<.04$ \\
\hline 01034 & Chromium, unfiltered & .05 & $<.21$ & .17 & $<.42$ & .2 & $<.42$ \\
\hline 01037 & Cobalt, unfiltered & .057 & $<.02$ & 1.33 & .08 & .366 & .09 \\
\hline 01042 & Copper, unfiltered & .8 & 3.9 & 8.5 & E1.3 & 2.4 & E.70 \\
\hline 01046 & Iron, filtered & 28 & 10 & 2,010 & 1,120 & 422 & 493 \\
\hline 01045 & Iron, unfiltered & 40 & 125 & 2,190 & 2,130 & 397 & 487 \\
\hline 01051 & Lead, unfiltered & .13 & 4.26 & .08 & .1 & $<.06$ & $<.06$ \\
\hline 01132 & Lithium, unfiltered & 29.6 & 37.4 & 42.0 & 37.5 & 7.7 & 7.1 \\
\hline 01056 & Manganese, filtered & 13.4 & 17.9 & 73.2 & 63.9 & 83.5 & 76 \\
\hline 01055 & Manganese, unfiltered & 13.8 & 20.3 & 72.0 & 81.5 & 81.8 & 81.8 \\
\hline 01062 & Molybdenum, unfiltered & 0.5 & .5 & 1.6 & 1.5 & 2.7 & 3 \\
\hline 01067 & Nickel, unfiltered & E.13 & $<.12$ & 9.21 & .82 & 1.68 & $<.36$ \\
\hline 01147 & Selenium, unfiltered & $<.08$ & $<.05$ & .16 & E.07 & E.05 & $<.10$ \\
\hline 01077 & Silver, unfiltered & $\mathrm{U}$ & $<.01$ & $\mathrm{U}$ & E.01 & U & $<.02$ \\
\hline 01082 & Strontium, unfiltered & 377 & 423 & 10,700 & 10,600 & 280 & 249 \\
\hline 01092 & Zinc, unfiltered & 20 & 19.1 & 7 & 3.1 & $<2$ & $<2.0$ \\
\hline 82303 & Radon-222, unfiltered, $\mathrm{pCi} / \mathrm{L}$ & 280 & 300 & 520 & 490 & 470 & 380 \\
\hline 28011 & Uranium, unfiltered & .032 & .032 & .239 & .222 & .405 & .275 \\
\hline
\end{tabular}

${ }^{1}$ Prefix denotes county: AG, Allegany; MO, Monroe; WO, Wyoming; number is local well-identification number assigned by U.S. Geological Survey. 
Table 1-12. Concentrations of pesticides in groundwater samples collected in the Genesee River Basin, New York, 2005-2006 and 2010.

[Well locations are shown in figure 1. All concentrations in micrograms per liter in filtered water. NWIS, National Water Information System; <, less than]

\begin{tabular}{|c|c|c|c|c|c|c|c|}
\hline $\begin{array}{l}\text { U.S. Geological } \\
\text { Survey NWIS } \\
\text { parameter code }\end{array}$ & Constituent & \multicolumn{2}{|c|}{ AG $263^{1}$} & \multicolumn{2}{|c|}{ MO $1524^{1}$} & \multicolumn{2}{|c|}{ WO $350^{1}$} \\
\hline 82660 & 2,6-Diethylaniline & $<0.006$ & $<0.006$ & $<0.006$ & $<0.006$ & $<0.006$ & $<0.006$ \\
\hline 04040 & $\begin{array}{l}\text { 2-Chloro-4-isopropylamino- } \\
\text { 6-amino-s-triazine (CIAT) }\end{array}$ & $<.006$ & $<.006$ & $<.006$ & $<.014$ & $<.006$ & $<.014$ \\
\hline 49260 & Acetochlor & $<.006$ & $<.010$ & $<.006$ & $<.010$ & $<.006$ & $<.010$ \\
\hline 34253 & alpha-HCH & $<.005$ & $<.004$ & $<.005$ & $<.004$ & $<.005$ & $<.004$ \\
\hline 39632 & Atrazine & $<.007$ & $<.008$ & $<.007$ & $<.007$ & $<.007$ & $<.007$ \\
\hline 82686 & Azinphos-methyl & $<.050$ & $<.120$ & $<.050$ & $<.120$ & $<.050$ & $<.120$ \\
\hline 82673 & Benfluralin & $<.010$ & $<.014$ & $<.010$ & $<.014$ & $<.010$ & $<.014$ \\
\hline 04028 & Butylate & $<.004$ & $<.004$ & $<.004$ & $<.004$ & $<.004$ & $<.004$ \\
\hline 82687 & cis-Permethrin & $<.006$ & $<.010$ & $<.006$ & $<.014$ & $<.006$ & $<.014$ \\
\hline 04041 & Cyanazine & $<.018$ & $<.022$ & $<.018$ & $<.022$ & $<.018$ & $<.022$ \\
\hline 82682 & DCPA & $<.003$ & $<.008$ & $<.003$ & $<.008$ & $<.003$ & $<.008$ \\
\hline 62170 & Desulfinylfipronil & $<.012$ & $<.012$ & $<.012$ & $<.012$ & $<.012$ & $<.012$ \\
\hline 39572 & Diazinon & $<.005$ & $<.006$ & $<.005$ & $<.005$ & $<.005$ & $<.005$ \\
\hline 39381 & Dieldrin & $<.009$ & $<.008$ & $<.009$ & $<.009$ & $<.009$ & $<.009$ \\
\hline 82677 & Disulfoton & $<.02$ & $<.04$ & $<.02$ & $<.04$ & $<.02$ & $<.04$ \\
\hline 82668 & EPTC & $<.004$ & $<.006$ & $<.004$ & $<.002$ & $<.004$ & $<.002$ \\
\hline 04095 & Fonofos & $<.003$ & $<.005$ & $<.003$ & $<.004$ & $<.003$ & $<.004$ \\
\hline 39341 & Lindane & $<.004$ & $<.004$ & $<.004$ & $<.004$ & $<.004$ & $<.004$ \\
\hline 82666 & Linuron & $<.035$ & $<.060$ & $<.035$ & $<.060$ & $<.035$ & $<.060$ \\
\hline 39532 & Malathion & $<.027$ & $<.016$ & $<.027$ & $<.016$ & $<.027$ & $<.016$ \\
\hline 82667 & Methyl parathion & $<.015$ & $<.008$ & $<.015$ & $<.008$ & $<.015$ & $<.008$ \\
\hline 39415 & Metolachlor & $<.006$ & $<.014$ & $<.006$ & $<.014$ & $<.006$ & $<.014$ \\
\hline 82630 & Metribuzin & $<.006$ & $<.012$ & $<.006$ & $<.012$ & $<.006$ & $<.012$ \\
\hline 82671 & Molinate & $<.003$ & $<.004$ & $<.003$ & $<.003$ & $<.003$ & $<.003$ \\
\hline 82684 & Napropamide & $<.007$ & $<.008$ & $<.007$ & $<.008$ & $<.007$ & $<.008$ \\
\hline 34653 & $\mathrm{p}, \mathrm{p}$-DDE & $<.003$ & $<.002$ & $<.003$ & $<.002$ & $<.003$ & $<.002$ \\
\hline 39542 & Parathion & $<.010$ & $<.020$ & $<.010$ & $<.020$ & $<.010$ & $<.020$ \\
\hline 82669 & Pebulate & $<.004$ & $<.016$ & $<.004$ & $<.016$ & $<.004$ & $<.016$ \\
\hline 82683 & Pendimethalin & $<.022$ & $<.012$ & $<.022$ & $<.012$ & $<.022$ & $<.012$ \\
\hline 82664 & Phorate & $<.011$ & $<.020$ & $<.011$ & $<.020$ & $<.011$ & $<.020$ \\
\hline
\end{tabular}


Table 1-12. Concentrations of pesticides in groundwater samples collected in the Genesee River Basin, New York, 2005-2006 and 2010.-Continued.

[Well locations are shown in figure 1. All concentrations in micrograms per liter in filtered water. NWIS, National Water Information System; <, less than]

\begin{tabular}{|c|c|c|c|c|c|c|c|}
\hline 04037 & Prometon & $<.01$ & $<.01$ & $<.01$ & $<.01$ & $<.01$ & $<.01$ \\
\hline 82676 & Propyzamide & $<.004$ & $<.004$ & $<.004$ & $<.004$ & $<.004$ & $<.004$ \\
\hline 04024 & Propachlor & $<.025$ & $<.006$ & $<.025$ & $<.006$ & $<.025$ & $<.006$ \\
\hline 82679 & Propanil & $<.011$ & $<.010$ & $<.011$ & $<.010$ & $<.011$ & $<.010$ \\
\hline 82685 & Propargite & $<.02$ & $<.02$ & $<.02$ & $<.02$ & $<.02$ & $<.02$ \\
\hline 04035 & Simazine & $<.005$ & $<.006$ & $<.005$ & $<.006$ & $<.005$ & $<.006$ \\
\hline 82670 & Tebuthiuron & $<.02$ & $<.03$ & $<.02$ & $<.03$ & $<.02$ & $<.03$ \\
\hline 82665 & Terbacil & $<.034$ & $<.024$ & $<.034$ & $<.024$ & $<.034$ & $<.024$ \\
\hline 82675 & Terbufos & $<.02$ & $<.02$ & $<.02$ & $<.02$ & $<.02$ & $<.02$ \\
\hline 82681 & Thiobencarb & $<.010$ & $<.016$ & $<.010$ & $<.016$ & $<.010$ & $<.016$ \\
\hline 82678 & Triallate & $<.006$ & $<.005$ & $<.006$ & $<.006$ & $<.006$ & $<.006$ \\
\hline 82661 & Trifluralin & $<.009$ & $<.018$ & $<.009$ & $<.018$ & $<.009$ & $<.018$ \\
\hline
\end{tabular}

${ }^{1}$ Prefix denotes county: AG, Allegany; MO, Monroe; WO, Wyoming; number is local well-identification number assigned by U.S. Geological Survey. 
Table 1-13. Concentrations of volatile organic compounds in groundwater samples collected in the Genesee River Basin, New York, 2005-2006 and 2010.

[Well locations are shown in figure 1. All concentrations in micrograms per liter in unfiltered water. NWIS, National Water Information System; <, less than. Bold values indicate detections]

\begin{tabular}{|c|c|c|c|c|c|c|c|}
\hline \multirow{2}{*}{$\begin{array}{c}\text { U.S. Geological } \\
\text { Survey NWIS } \\
\text { parameter } \\
\text { code }\end{array}$} & \multirow{2}{*}{ Constituent } & \multicolumn{2}{|c|}{ AG 2631} & \multicolumn{2}{|c|}{ MO 15241} & \multicolumn{2}{|c|}{ WO 3501} \\
\hline & & 2005-2006 & 2010 & 2005-2006 & 2010 & 2005-2006 & 2010 \\
\hline 34506 & 1,1,1-Trichloroethane & $<0.1$ & $<0.1$ & $<0.1$ & $<0.1$ & $<0.1$ & $<0.1$ \\
\hline 77652 & $\begin{array}{l}\text { 1,1,2-Trichloro-1,2,2-trifluoro- } \\
\text { ethane (CFC-113) }\end{array}$ & $<.1$ & $<.1$ & $<.1$ & $<.1$ & $<.1$ & $<.1$ \\
\hline 34496 & 1,1-Dichloroethane & $<.1$ & $<.1$ & $<.1$ & $<.1$ & $<.1$ & $<.1$ \\
\hline 34501 & 1,1-Dichloroethene & $<.1$ & $<.1$ & $<.1$ & $<.1$ & $<.1$ & $<.1$ \\
\hline 34536 & 1,2-Dichlorobenzene & $<.1$ & $<.1$ & $<.1$ & $<.1$ & $<.1$ & $<.1$ \\
\hline 32103 & 1,2-Dichloroethane & $<.2$ & $<.2$ & $<.2$ & $<.2$ & $<.2$ & $<.2$ \\
\hline 34541 & 1,2-Dichloropropane & $<.1$ & $<.1$ & $<.1$ & $<.1$ & $<.1$ & $<.1$ \\
\hline 34566 & 1,3-Dichlorobenzene & $<.1$ & $<.1$ & $<.1$ & $<.1$ & $<.1$ & $<.1$ \\
\hline 34571 & 1,4-Dichlorobenzene & $<.1$ & $<.1$ & $<.1$ & $<.1$ & $<.1$ & $<.1$ \\
\hline 34030 & Benzene & $<.1$ & $<.1$ & $<.1$ & $<.1$ & $<.1$ & $<.1$ \\
\hline 32101 & Bromodichloromethane & $<.1$ & $<.1$ & $<.1$ & .4 & $<.1$ & $<.1$ \\
\hline 32104 & Tribromomethane & $<.2$ & $<.2$ & $<.2$ & $<.2$ & $<.2$ & $<.2$ \\
\hline 34301 & Chlorobenzene & $<.1$ & $<.1$ & $<.1$ & $<.1$ & $<.1$ & $<.1$ \\
\hline 77093 & cis-1,2-Dichloroethene & $<.2$ & $<.1$ & $<.2$ & $<.1$ & $<.2$ & $<.1$ \\
\hline 32105 & Dibromochloromethane & $<.2$ & $<.2$ & $<.2$ & .2 & $<.2$ & $<.2$ \\
\hline 34668 & Dichlorodifluoromethane & $<.2$ & $<.2$ & $<.2$ & $<.2$ & $<.2$ & $<.2$ \\
\hline 34423 & Dichloromethane & $<.2$ & $<.2$ & $<.2$ & $<.2$ & $<.2$ & $<.2$ \\
\hline 81576 & Diethyl ether & $<.2$ & $<.2$ & $<.2$ & $<.2$ & $<.2$ & $<.2$ \\
\hline 81577 & Diisopropyl ether & $<.2$ & $<.2$ & $<.2$ & $<.2$ & $<.2$ & $<.2$ \\
\hline 34371 & Ethylbenzene & $<.1$ & $<.1$ & $<.1$ & $<.1$ & $<.1$ & $<.1$ \\
\hline 50005 & Methyl tert-pentyl ether & $<.2$ & $<.2$ & $<.2$ & $<.2$ & $<.2$ & $<.2$ \\
\hline 85795 & m- + p-Xylene & $<.2$ & $<.2$ & $<.2$ & $<.2$ & $<.2$ & $<.2$ \\
\hline 77135 & o-Xylene & $<.1$ & $<.1$ & $<.1$ & $<.1$ & $<.1$ & $<.1$ \\
\hline 77128 & Styrene & $<.1$ & $<.1$ & $<.1$ & $<.1$ & $<.1$ & $<.1$ \\
\hline 50004 & tert-Butyl ethyl ether & $<.2$ & $<.1$ & $<.2$ & $<.1$ & $<.2$ & $<.1$ \\
\hline 78032 & Methyl tert-butyl ether (MTBE) & $<.2$ & $<.2$ & $<.2$ & $<.2$ & $<.2$ & $<.2$ \\
\hline 34475 & Tetrachloroethene & $<.1$ & $<.1$ & $<.1$ & $<.1$ & $<.1$ & $<.1$ \\
\hline 32102 & Tetrachloromethane & $<.1$ & $<.2$ & $<.1$ & $<.2$ & $<.1$ & $<.2$ \\
\hline 34010 & Toluene & $<.1$ & .3 & $<.1$ & $<.1$ & $<.1$ & $<.1$ \\
\hline 34546 & trans-1,2-Dichloroethene & $<.1$ & $<.1$ & $<.1$ & $<.1$ & $<.1$ & $<.1$ \\
\hline 39180 & Trichloroethene & $<.1$ & $<.1$ & $<.1$ & $<.1$ & $<.1$ & $<.1$ \\
\hline 34488 & $\begin{array}{l}\text { Trichlorofluoromethane } \\
\text { (CFC-11) }\end{array}$ & $<.1$ & $<.2$ & $<.1$ & $<.2$ & $<.1$ & $<.2$ \\
\hline 32106 & Trichloromethane & $<.1$ & $<.1$ & $<.1$ & 1.3 & $<.1$ & $<.1$ \\
\hline 39175 & Vinyl chloride & $<.2$ & $<.2$ & $<.2$ & $<.2$ & $<.2$ & $<.2$ \\
\hline
\end{tabular}

${ }^{1}$ Prefix denotes county: AG, Allegany; MO, Monroe; WO, Wyoming; number is local well-identification number assigned by U.S. Geological Survey. 
This page has been left blank intentionally. 
Prepared by the Pembroke and Reston Publishing Service Centers

For additional information write to:

New York Water Science Center

U.S. Geological Survey

30 Brown Rd.

Ithaca, NY 14850

Information requests:

(518) 285-5602

or visit our Web site at:

http://ny.water.usgs.gov 
$\frac{\mathbb{R}}{50}$

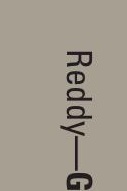

